\title{
Sovereign Default Risk and the U.S. Equity Market
}

\author{
Alexandre Jeanneret*
}

\begin{abstract}
This paper develops a two-country asset pricing model with defaultable firms and governments. This model shows that higher sovereign credit risk in a country depresses equity prices internationally and increases their volatility. The effect is strongest during adverse economic conditions and when firms are close to financial distress. A structural estimation provides evidence that sovereign default risk in Europe affects European and U.S. stock markets through the threat of an economic slowdown.
\end{abstract}

\section{Introduction}

The recent sovereign debt crisis in Europe has shown that international investors pay close attention to news related to sovereign default risk and appear to value equities accordingly. ${ }^{1}$ Stock markets are thus expected to fall when

*Jeanneret (corresponding author), alexandre.jeanneret@hec.ca, Department of Finance, HEC Montréal. I am very grateful for comments and suggestions from an anonymous referee, Daniel Andrei, Philippe Bacchetta, Kenza Benhima, Hendrik Bessembinder (the editor), Harjoat Bhamra, Michael Brennan, Julien Cujean, Georges Dionne, Christian Dorion, Darrell Duffie, Bernard Dumas, Ruediger Fahlenbrach, Thierry Foucault, Mathieu Fournier, Pascal François, Jeffrey A. Frankel, Laurent Frésard, Geneviève Gauthier, Rajna Gibson, Gunnar Grass, Michael Hasler, Ricardo Hausmann, Christopher Hennessy, Julien Hugonnier, Jean Imbs, Robert Merton, Erwan Morellec, Boris Nikolov, Anna Pavlova (discussant), Aude Pommeret, Norman Schuerhoff, Eduardo Schwartz, Philip Valta, Wei Yang (discussant), and participants at the 2010 Bank of Canada Conference in Ottawa, 2010 CREDIT Conference in Venice, 2011 Mathematical Finance Days in Montréal (conference paper award), 2012 Western Finance Association (WFA), Copenhagen Business School, EDHEC Business School, HEC Montréal, Norwegian School of Management, Rice University, University of Amsterdam, University of Houston, University of Lausanne, and Vienna Graduate School of Finance (GSF) for helpful comments. I acknowledge the financial support from Swiss Finance Institute and the National Centre of Competence in Research (NCCR) Financial Valuation and Risk Management (FINRISK), managed by the Swiss National Science Foundation, HEC Montréal, Institut de Finance Mathématique de Montréal (IFM2), and the Fonds Québécois de la Recherche sur la Société et la Culture (FQRSC). All errors are mine.

${ }^{1}$ The reaction of financial markets to European sovereign default risk has been regularly reported by the financial press. See, for example, "Europe Fears Rock Markets" (Financial Times, Feb. 5, 2010), "U.S. Stocks Drop as Sovereign Debt Concerns Overshadow Data" (Bloomberg, Mar. 30, 2010), "Greek Fears Hit Global Stocks, Bond Spreads" (Reuters, Apr. 8, 2010), "Global Markets Tumble on Continued Worries over Europe's Debt Crisis" (The New York Times, July 11, 2011), and "Dow Drops 520 amid New Europe Debt Concern" (Bloomberg, Aug. 11, 2011). 
sovereign credit risk increases (see Figure 1). Yet it is difficult to identify a causal relationship in the data because equity market prices and the probability of sovereign default are interdependent: They respond to the same economic shocks. This endogeneity problem has not been resolved thus far due to our limited understanding of the interactions among the risk of sovereign default, economic fundamentals, and international asset prices. This paper sheds light on this issue with a model that unifies the endogenous determination of sovereign credit risk and stock prices across countries.

The aim of this paper is to help explain how sovereign default risk affects international stock markets and to determine how this effect varies over time. I propose to investigate the transmission mechanism with a model that embeds the valuation of levered firms and sovereign default risk in a consumption-based international asset pricing model. The model shows that a rise in the risk of a sovereign default crisis in a country translates into the risk of a temporary economic slowdown, which in turn affects firm valuation across countries. Sovereign default risk thus negatively impacts international equity markets, particularly when economic conditions deteriorate. A structural estimation of the model measures the expected economic costs of a sovereign default crisis, as implied by financial asset prices. This analysis helps quantify the impact of sovereign default risk on international equity markets, thus complementing the existing evidence on the ex post consequences of observed sovereign defaults.

The model consists of an economy with two countries, Domestic and Foreign, which can be viewed as the United States and Europe. Each country has a set of heterogeneous firms that raise revenue by producing a country-specific good. Firms pay taxes to their governments and are financed by equity and debt. Each firm has an optimal default policy that depends on its profitability. There is a representative risk-averse agent in each country who owns and provides labor to the domestic firms, lends to its government, and consumes the local good.

\section{FIGURE 1}

\section{Sovereign Credit Risk, Equity Markets, and the EUR/USD Exchange Rate (2008-2010)}

Graph A of Figure 1 illustrates the relationship between sovereign credit risk in Europe and equity markets in the United States (Standard \& Poor's (S\&P) 500 index) and Europe (Euro Stoxx 600 index). Graph B exhibits the relationship between sovereign credit risk and the EUR/USD exchange rate. The measure of sovereign credit risk is the Greek 10-year credit default swap (CDS) spread, and bps stands for basis points.
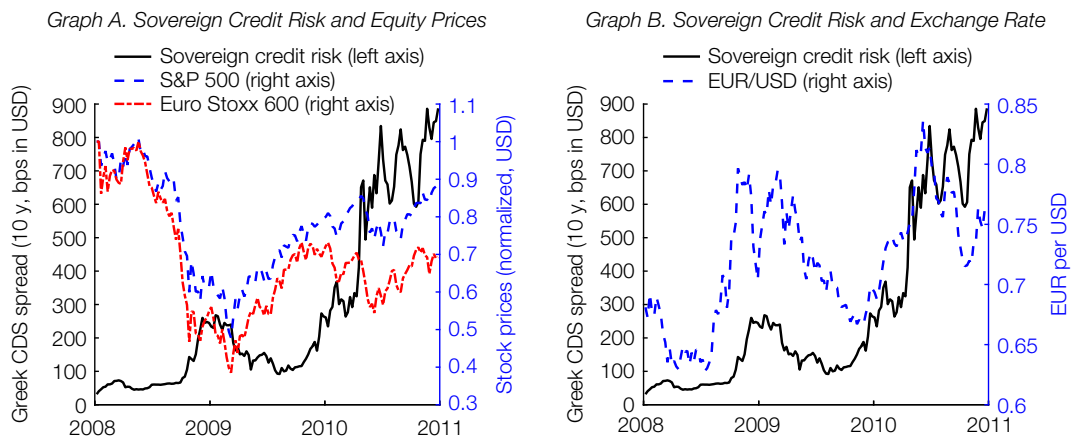
Firm securities are priced in the presence of a government that has the option of defaulting on its debt.

This model extends the corporate finance and asset pricing literature in two ways. It first allows shareholders' default policy and asset valuation to depend on the risk of a sovereign debt crisis, which would have adverse consequences for the economy. Second, it incorporates credit risk into an international asset pricing environment, in which economic shocks propagate across countries. The paper thus endogenizes sovereign and corporate default risk along with international asset prices in a unified framework, whereas the existing literature has thus far considered these dimensions separately. ${ }^{2}$ The proposed setting is thus particularly relevant to study the complex interactions between international stock markets and sovereign default risk. On the one hand, sovereign credit risk and equity prices comove because they respond to the same economic shocks. On the other hand, the risk of sovereign default captures information about future economic growth and thus directly impacts equity prices.

To grasp the intuition behind these predictions, consider a negative production shock in one country. This shock decreases firm revenue in both countries through international risk sharing. The market values of equity are reduced, which internationally increases financial leverage and equity return volatility. ${ }^{3}$ Moreover, less firm revenue means that the government's fiscal situation deteriorates, which is reflected in greater credit risk. Sovereign credit spreads thus increase during adverse economic conditions, when equity prices decline and become more volatile. Hence, this theory demonstrates that some comovement can arise without causality.

In addition, sovereign default risk directly affects equity markets because a sovereign default is expected to temporarily lower economic growth. Thus, a negative shock not only immediately reduces firm revenue but also increases the likelihood of an economic slowdown, which propagates internationally through two channels. First, the real exchange rate adjusts to the shock, which affects the terms of trade, following Pavlova and Rigobon (2007), Verdelhan (2010), and Colacito and Croce (2011), among others. ${ }^{4}$ Second, lower economic growth triggers an incentive to rebalance portfolios toward risk-free securities, as noted by Kyle and Xiong (2001) and Cochrane, Longstaff, and Santa-Clara (2008). The lower risk-free rate raises firm financial leverage (i.e., a relative increase in market debt value), thus encouraging shareholders to default more rapidly.

\footnotetext{
${ }^{2}$ Existing corporate finance theory (e.g., Bhamra, Kuehn, and Strebulaev (2010a), (2010b), Chen (2010)) values firm assets with different regimes but in a single country, Andrade (2009) and Jeanneret (2015) study the sovereign default decision and its impact on domestic unlevered firms, and the international asset pricing literature (e.g., Pavlova and Rigobon (2007), Verdelhan (2010), and Colacito and Croce (2011)) helps understand the transmission of shocks across countries in the absence of default risk.

${ }^{3}$ This prediction is in line with the evidence documented by Schwert (1989), Forbes and Rigobon (2002), Bae, Karolyi, and Stulz (2003), Engle and Rangel (2008), and Engle, Ghysels, and Sohn (2013), among others.

${ }^{4}$ Consistent with this prediction, Della Corte, Sarno, Schmeling, and Wagner (2015) provide evidence that sovereign credit risk affects currencies, and Figure 1 illustrates a positive relationship between European sovereign credit risk and the euro/dollar exchange rate. Further, Bae et al. (2003) and Ehrmann, Fratzscher, and Rigobon (2011) find evidence that movements in exchange rates help explain contagion across international equity markets.
} 
The main prediction of the model is that the risk of sovereign default amplifies, through its potential impact on economic growth, the sensitivity of international equities to economic shocks. The effect of sovereign default risk is predicted to be strongest in downturns and when firms are financially vulnerable. This theory thus contributes to understanding the negative equity returns accompanied by high peaks in equity return volatility observed during periods of high sovereign credit risk, such as during the recent European debt crisis. Most important, it allows disentangling a causal relationship from the joint response to common shocks.

A structural estimation assesses the quantitative performance of the model. Using the generalized method of moments (GMM), I estimate the expected economic slowdown following sovereign default that explains a set of key empirical moments in the euro area (18 countries) and the United States over the period Jan. 1991-Dec. 2013. The results indicate that a decline in economic growth in the case of sovereign default is expected to be 5\% per annum and to last 2.5 years. Both estimates are statistically significant and consistent with the evidence regarding previous defaults. ${ }^{5}$

The model indicates that European sovereign default risk reduces U.S. equity prices by $3.6 \%$ on average, with the reduction varying over time between $0.7 \%$ and $18 \%$ over the sample period. The increase in the volatility of U.S. equity returns equals $1.3 \%$ on average and varies between $0.2 \%$ and $9.3 \% .^{6}$ The effect of sovereign default risk on equity prices is thus economically large, particularly when firms are financially distressed (i.e., the recent U.S. crisis) and sovereign default risk in Europe is severe. Importantly, these results are free of potential endogeneity concerns. This is because the model makes it possible to structurally isolate the direct effect of sovereign default risk on equity markets by controlling for the possible comovement arising from the common response to economic shocks.

This paper also provides insights into the conditional probability of a European sovereign crisis. For this exercise, I consider a structural calibration that matches the average ratio of debt to gross domestic product (GDP) in Europe and the unconditional 10-year default probability in the data. The probability of sovereign default in Europe is predicted to peak during the European monetary crisis of 1992-1993 (above 25\%) and the U.S. financial crisis of 20082010 (above 50\%) but to remain negligible over the 1999-2007 period (less than $0.1 \%$ ). Hence, the extremely narrow sovereign spreads observed in Europe between the creation of the euro in 1999 and the beginning of the U.S. financial

\footnotetext{
${ }^{5}$ For example, Dias and Richmond (2009) and Gelos, Sahay, and Sandleris (2011) find that the median length of sovereign crises is 3 and 2 years, respectively. De Paoli, Hoggarth, and Saporta (2009) obtain a median estimate of output loss of 5.25\% per year, and Mendoza and Yue (2012) report an average estimate of $5 \%$.

${ }^{6}$ In a related line of research, Pan and Singleton (2008), Remolona, Scatigna, and Wu (2008), Hilscher and Nosbusch (2010), and Longstaff, Pan, Pedersen, and Singleton (2011) investigate the empirical relationship between sovereign credit spreads and the option-implied volatility index on the S\&P 500 (VIX). Whereas the current paper analyzes the effect of the probability of sovereign default on the U.S. equity market in a structural framework, these studies focus on the empirical relationship between the volatility risk premium embedded in the VIX and the pricing of sovereign credit risk. These two lines of research complement one another.
} 
crisis appear to be consistent with the underlying economic conditions during that period.

As a final analysis, the paper determines the welfare costs of a sovereign default for local consumers, which arises from the decline in their expected consumption growth. Following Lucas (1987), I quantify the consumption level that European agents would demand to become indifferent between a consumption path without sovereign default risk and the compensated path with a temporary lower growth rate during the sovereign crisis. The welfare costs amount to $11.9 \%$ of consumption at the time of sovereign default, which corresponds to $4.4 \%$ in present value. This finding suggests that sovereign default risk not only induces losses for international investors, in terms of reduced asset values, but also entails substantial costs to European households.

Overall, the results of this paper suggest that sovereign default risk strongly affects financial markets and the real economy through the risk of an economic slowdown. One explanation for the lower economic growth following a sovereign default is the reduced solvency of European banks via losses on their highly concentrated holdings of sovereign debt. ${ }^{7}$ In the case of a sovereign default crisis, the losses on bank balance sheets would in turn hamper credit and investment and, eventually, affect the pace of the economy. This paper thus complements the literature exploring the link between sovereign defaults and economic activity. ${ }^{8}$

This paper relates to a number of theoretical studies belonging to separate strands of the literature. First, the foundation for the paper is an international consumption-based model with representative risk-averse agents, following Pavlova and Rigobon (2007), Verdelhan (2010), Colacito and Croce (2011), Bansal and Shaliastovich (2012), and Gourio, Siemer, and Verdelhan (2013), which I extend by incorporating heterogeneous levered firms and sovereign default risk. The government's decision to default and its consequences for economic activity follow the work of Cohen and Sachs (1986), Bulow and Rogoff (1989), Arellano (2008), Andrade (2009), Hatchondo and Martinez (2009), Yue (2010), Borri and Verdelhan (2012), and Jeanneret (2015), among others. The evaluation of firm assets is related to Bhamra et al. (2010a), (2010b) and Chen (2010), who embed firms with exogenous macroeconomic regimes (Hackbarth, Miao, and Morellec (2006)) in a consumption-based asset pricing model. This line of research builds upon the structural models in corporate finance that analyze endogenous default and debt policies (e.g., Mello and Parsons (1992), Leland (1994)).

The remainder of the paper is organized as follows: Section II outlines an international asset pricing model with firms and governments. Section III discusses the calibration of the model. Section IV offers theoretical predictions on equity

\footnotetext{
${ }^{7}$ As an illustration, the exposure of the French and German banking sectors to the bonds of financially distressed states (Portugal, Ireland, Greece, and Spain) amounted to 550 billion euros in 2010, representing 13\% of France and Germany's combined GDP (Citigroup (2011)). Interestingly, the European episode would by no means be an exception. The same link connecting government default, bank balance sheets, and a decline in credit has been consistently observed in previous sovereign debt crises (Gennaioli, Martin, and Rossi (2014)).

${ }^{8}$ See, for example, Broner, Martin, and Ventura (2010), Bolton and Jeanne (2011), Acharya and Rajan (2013), Acharya, Drechsler, and Schnabl (2014), and Gennaioli et al. (2014).
} 
prices, equity return volatility, and the probability of sovereign default. Section V consists of a structural estimation of the model, and Section VI concludes the analysis.

\section{Model}

This section presents the model. First, it introduces the economic environment, the agents' preferences, and the equilibrium real exchange rate. Second, it provides details on firm characteristics and their asset valuation, and then describes the government's default policy. Finally, it discusses the characteristics of the financial markets implied by the model.

\section{A. Environment}

I consider a continuous-time pure-exchange world economy along the lines of Lucas (1982). There are two countries: Domestic and Foreign. In each country, firms produce a perishable good via a strictly positive output process modeled as a Lucas tree. The tax environment consists of a constant tax rate for corporate earnings and labor income and a zero tax rate for consumption and financial income.

\section{Domestic and Foreign Output}

Let $X_{d, t}$ denote the perpetual stream of Domestic output at time $t$, which evolves according to the process

$$
\frac{d X_{d, t}}{X_{d, t}}=\theta_{d} d t+\sigma_{d} d W_{t}^{d},
$$

where $W_{t}^{d}$ is a Brownian motion defined on the probability space $(\Omega, \mathscr{F}, \mathbb{P})$. The standard filtration of $W_{t}^{d}$ is $F_{d}=\left\{\mathscr{F}_{t}: t \geq 0\right\}$. The conditional moments $\theta_{d}$ and $\sigma_{d}$ represent the expected growth rate and the volatility of Domestic output. This country has a default-free government.

The dynamics of the perpetual stream of output in the Foreign country are governed by the process

$$
\frac{d X_{f, t}}{X_{f, t}}=\theta_{f, s} d t+\sigma_{f} d W_{t}^{f}, \quad s=\{L, H\},
$$

where $W_{t}^{f}$ is a Brownian motion defined on the probability space $(\Omega, \mathscr{F}, \mathbb{P})$ and correlated with $W_{t}^{d}$ such that $d W_{t}^{d} d W_{t}^{f}=\rho d t$, and $\rho$ is the correlation coefficient. The standard filtration of $W_{t}^{f}$ is $F_{f}=\left\{\mathscr{F}_{t}: t \geq 0\right\}$, and the volatility of Foreign production is denoted by $\sigma_{f}$. $W_{t}^{d}$ and $W_{t}^{f}$ are the only sources of shocks in the model.

The Foreign country is subject to a temporary change in regime. This economy is characterized by two states of growth: a high state $H$ and a low state $L$, such that $\theta_{f, H}-\theta_{f, L}=\Delta \theta>0$. The change in state from $s=H$ to $s=L$ occurs when the Foreign government defaults. ${ }^{9}$ There is an exogenous intensity

\footnotetext{
${ }^{9}$ The economic slowdown induced by the sovereign default is ad hoc in the model. As discussed in Section V.E, the banking sector seems to be an important transmission channel: Sovereign default crises tend to prevent domestic banks from providing liquidity and credit to firms, thereby lowering economic growth.
} 
$\lambda_{L H}$ such that the probability that the regime returns to the predefault state $(s=H)$ over the next infinitesimal time instant $d t$ is $\lambda_{L H} d t$. This feature follows Aguiar and Gopinath (2006), Arellano (2008), and Borri and Verdelhan (2012).

\section{Preferences}

In each country, there is a representative agent with logarithmic preferences who maximizes expected utility

$$
\mathbb{E} \int_{0}^{\infty} e^{-\beta t} u\left(y_{j, t}\right) d t,
$$

where $\beta$ is the rate of time preference, $y_{j, t}$ denotes consumption of country $j$ 's agent, and the subscript $j=\{d, f\}$ indicates the Domestic and the Foreign countries, respectively. The instantaneous utility function is $u\left(y_{j, t}\right) \equiv \log \left(y_{j, t}\right)$, and $u_{j}\left(y_{j, t}\right)$ equals the marginal utility of country $j$ 's agent with respect to its local good.

Logarithmic preferences have the property to generate perfect international risk sharing (see Zapatero (1995), Pavlova and Rigobon (2007)), which is an important feature for the valuation of assets in a two-country model with multiple defaults. ${ }^{10}$ To simplify the model, I assume complete home bias, meaning that each country's representative agent is willing to consume only the good with which he or she is endowed. ${ }^{11}$ An equilibrium of this economy exists, in which each country behaves as an autarky both for consumption and asset holdings (see Verdelhan (2010), Colacito and Croce (2011)).

\section{Prices and Numeraire}

The prices per unit of the Domestic good $X_{d, t}$ and the Foreign good $X_{f, t}$ are denoted by $P_{d, t}$ and $P_{f, t}$, respectively. I treat an aggregate consumption basket as the numeraire, where each country's consumption (i.e., production) is weighted by its share in world output, as noted by Pavlova and Rigobon (2007).

From Obstfeld and Rogoff (1996), it can be shown that in the Cobb-Douglas case of an aggregate constant-elasticity-of-substitution (CES) consumption basket, the price of this basket is a geometric average of prices $P_{d, t}$ and $P_{f, t}$. The weights are $\alpha \in(0,1)$ and $1-\alpha$, respectively, where $\alpha$ corresponds to the size of Domestic production in terms of world production (see Internet Appendix A, available at www.jfqa.org). ${ }^{12}$ I normalize the price of this basket to be equal to unity (i.e., $P_{d, t}^{\alpha} P_{f, t}^{1-\alpha}=1$ ) and value output and assets in units of that basket.

\footnotetext{
${ }^{10}$ Beyond the logarithmic case, output (consumption) value becomes imperfectly correlated across countries. It is then impossible to determine whether a Domestic firm defaults before or after the regime change (i.e., the Foreign government defaults). Section V.F discusses this point in greater detail.

${ }^{11}$ These preferences follow the recent literature in international asset pricing, which includes Brandt, Cochrane, and Santa-Clara (2006), Verdelhan (2010), Colacito and Croce (2011), Bansal and Shaliastovich (2012), and Gourio et al. (2013), among others. Essentially, the environment is characterized by complete markets but in which frictions in goods markets prevent any net trade. Autarky is not a restrictive assumption because the transmission of shocks across countries remains identical with and without international trade.

${ }^{12}$ In addition to the economic justification for the geometric average, the arithmetic average (e.g., $\left.\alpha X_{d, t}+(1-\alpha) X_{f, t}\right)$ would be less tractable for the analysis of asset prices because it does not allow for analytical solutions of the first two moments of asset returns.
} 


\section{Real Exchange Rate}

I now introduce the real exchange rate, denoted by $S_{t}$, which corresponds to the terms of trade (see Dumas (1992)). It is defined as the price of the Domestic good $P_{d, t}$ per unit of the price of the Foreign good $P_{f, t}$ and equals (see Internet Appendix B)

$$
S_{t}=\frac{P_{d, t}}{P_{f, t}}=\frac{u_{d}\left(y_{d, t}\right)}{u_{f}\left(y_{f, t}\right)}=\frac{X_{f, t}}{X_{d, t}},
$$

which is also given by the ratio of the country's marginal utilities of the Domestic and Foreign goods. ${ }^{13}$ The real exchange rate adjusts to make no aggregate trade an equilibrium. ${ }^{14}$

The real exchange rate plays an important role in the propagation of shocks from one country to another. A negative shock to Foreign output $\left(X_{f, t}\right)$ lowers the price of the Domestic good $\left(P_{d, t}\right)$, which becomes relatively less scarce. The improvement in the terms of trade thus reduces the value of Domestic output $\left(P_{d, t} X_{d, t}\right)$, despite the level of Domestic production $\left(X_{d, t}\right)$ remaining unchanged. The price of the Domestic good decreases until each country's marginal utilities are equalized and the incentives to trade vanish. The international transmission of shocks thus consists of a pure relative price effect.

\section{International Risk Sharing and State-Price Density}

The real exchange rate allows converting the value of each country's output under a common numeraire. In equilibrium, the value of Domestic and Foreign output is given by (see Internet Appendix C.1)

$$
P_{d, t} X_{d, t}=P_{f, t} X_{f, t}=X_{d, t}^{\alpha} X_{f, t}^{1-\alpha} \equiv X_{t},
$$

where $X_{t}$ is the aggregation of output across countries. Equation (5) indicates that the value of output depends on the relative production across countries, despite each agent consuming his or her local good only. Shocks in a country are then perfectly shared with the other country through the real exchange rate.

The output value in both countries satisfies the dynamics

$$
\frac{d X_{t}}{X_{t}}=\theta_{X, s} d t+\sigma_{X, d} d W_{t}^{d}+\sigma_{X, f} d W_{t}^{f},
$$

where the expressions for $\theta_{X, s}, \sigma_{X, d}$, and $\sigma_{X, f}$ are given in Internet Appendix C.2. A decline in the Foreign country's growth rate (from $\theta_{f, H}$ to $\theta_{f, L}$ ) has an impact on the output value in both countries (i.e., $\theta_{X, L}<\theta_{X, H}$ ).

\footnotetext{
${ }^{13}$ In a competitive equilibrium, the price of 1 unit of the Domestic good to be delivered at time $t$ in state $w$ is $\xi_{d, t}=P_{d, t} \xi_{t}$, and the price of 1 unit of the Foreign good to be delivered at time $t$ in state $w$ is $\xi_{f, t}=P_{f, t} \xi_{t}$, where $\xi_{t}$ is the state-price density in units of the world numeraire. Following Backus, Foresi, and Telmer (2001), Brandt et al. (2006), and Bakshi, Carr, and Wu (2008), the real exchange rate can also be expressed as the ratio of $\xi_{d, t}$ and $\xi_{f, t}$. The two approaches are identical.

${ }^{14}$ As Gourio et al. (2013) note, agents can always write state-contingent contracts that specify the delivery of goods in either country in any state of the world. In a similar vein, the risk-free asset is in zero net supply and, thus, not held in equilibrium. Although agents are free to consider buying it, the risk-free rate adjusts such that there is no net trade in this asset.
} 
The equilibrium state-price density is driven by the same set of shocks that drives aggregate output $X_{t}$. As economic shocks affect the marginal utility of investors through today's consumption levels, the risk price of these shocks rises with volatility in both countries and with the correlation in output across countries. The state-price density thus follows the process defined by (see Internet Appendix D)

$$
\frac{d \xi_{t}}{\xi_{t}}=-r_{s} d t-\sigma_{X, d} d W_{t}^{d}-\sigma_{X, f} d W_{t}^{f},
$$

where $r_{s}$ is the equilibrium risk-free rate prevailing in equilibrium in state $s$, which equals

$$
r_{s}=\beta+\theta_{X, s}-\left(\sigma_{X, d}^{2}+\sigma_{X, f}^{2}+2 \rho \sigma_{X, d} \sigma_{X, f}\right),
$$

which implies that higher uncertainty and lower economic growth induce greater demand for the risk-free bond, thereby reducing the equilibrium interest rate.

\section{B. Firms}

Each country consists of a continuum of firms, characterized by the subscript $i$, that produce and sell the local good. Firms have identical revenue but differ in their operating costs. They are thus heterogeneous in profitability within and across countries.

\section{Revenue}

Firm $i$ in country $j$ produces a quantity $X_{i j, t}$ that is sold at a price $P_{j, t}$. Firm revenue, denoted $R_{i, t} \equiv X_{i j, t} P_{j, t}$, satisfies (see Internet Appendix E.1)

$$
\frac{d R_{i, t}}{R_{i, t}}=\theta_{X, s} d t+\sigma_{X, d} d W_{t}^{d}+\sigma_{X, f} d W_{t}^{f},
$$

which implies that firms of the same country generate identical revenue dynamics because they sell the same good at the same price. In addition, firm revenue has the same dynamics across countries due to international risk sharing.

To price assets in this economy, agents discount cash flows with the riskfree rate under the risk-neutral probability measure $\mathbb{Q}$, which adjusts for risks by changing the distribution of shocks. Firm cash flows are risky for an investor because they are correlated with its marginal utility, which is accounted for by lowering the expected growth rate of firm revenue under $\mathbb{Q}$ (see Internet Appendix E.2):

$$
\tilde{\theta}_{X, s}=\theta_{X, s}-\left(\sigma_{X, d}^{2}+\sigma_{X, f}^{2}+2 \rho \sigma_{X, d} \sigma_{X, f}\right) .
$$

\section{Operating Costs and Capital Structure}

Firm $i$ in country $j$ bears operating costs $I_{i j, t}$, which are drawn from a country-specific cumulative distribution function $G\left(I_{j}\right)$. These operating (or production) costs represent the labor income paid to the country's resident. Unlevered firm earnings, denoted $U_{i j, t}$, are defined as follows:

$$
U_{i j, t} \equiv P_{j, t} X_{i j, t}-I_{i j, t} .
$$


Firms pay corporate taxes on these earnings at a rate $\tau_{j}$. Issuing debt generates tax benefits, and firms thus choose to be financed by equity and debt. The capital structure is characterized by an infinite-maturity debt with coupons $C_{j, t}^{F}{ }^{15}$ All firms of the same country have the same capital structure. However, financial leverage varies across both firms and countries due to heterogeneity in profitability.

\section{Stationary Leverage}

Leverage ratios tend to be stationary (see Collin-Dufresne and Goldstein (2001), Hovakimian, Opler, and Titman (2001)), thus suggesting that firms issue additional debt and raise their operating costs in response to an increase in firm value.

To account for this feature, the model considers firms with stable long-term operational and financial leverage ratios. I assume that the debt coupon and operating costs grow at the same rate as the long-term growth rate of firm revenue, such that the ratio $\left(C_{j, t}^{F}+I_{i j, t}\right) / R_{i, t}$ remains stationary. Hence, the debt coupon in country $j$ and operating costs of firm $i$ in country $j$ are given by (see Internet Appendix F)

$$
C_{j, t}^{F} \equiv g_{t} C_{j, 0}^{F} \text { and } I_{i j, t} \equiv g_{t} I_{i j, 0},
$$

where $g_{t}$ denotes the expected growth in firm revenue up to time $t$, which is determined by

$$
g_{t} \equiv \mathbb{E}_{0}\left[\left.\frac{R_{i, t}}{R_{i, 0}}\right|_{s=H}\right]=e^{\theta_{X, H} t}
$$

The expected growth in firm revenue $g_{t}$ depends only on the state $s=H$. First, $g_{t}$ captures the growth in firm revenue over the long run, which is almost certainly characterized by the state $s=H$ when $t \rightarrow \infty$ and $\lambda_{L H}>0$ (i.e., the state $s=L$ is temporary). Second, this choice allows debt issuance to outpace the growth in firm revenue in the temporary recession state $(s=L)$, in line with the evidence that aggregate debt issues (relative to firm value) vary countercyclically (see Korajczyk and Levy (2003)).

A desirable feature of the proposed capital and operating cost structure is that firms maintain long-term target leverage ratios and, simultaneously, display short-term variation in leverage. In addition, this approach does not require the introduction of financing frictions. ${ }^{16}$

\footnotetext{
${ }^{15}$ The level of debt is assumed to be exogenous for two reasons. First, firm leverage typically deviates from "optimal leverage" over time (see Strebulaev (2007), Bhamra et al. (2010a), (2010b)). Second, in the calibration, the capital structure is selected to match the level of financial leverage in the data (see Section V).

${ }^{16}$ Alternatively, dynamic refinancing models account for debt issuance costs to generate countercyclicality in leverage (e.g., Goldstein, Ju, and Leland (2001), Strebulaev (2007)). Morellec, Nikolov, and Schürhoff (2012) show that such models require debt issuance costs to be an order of magnitude higher than those observed in the data to explain the dynamics of financial leverage and refinancing cycles. They suggest that the presence of agency conflicts helps alleviate this problem.
} 


\section{Financial Claims}

The presence of corporate debt generates a risk of default that occurs at time $T_{i j}^{D}$ for firm $i$ located in country $j$. The default time is endogenous and determined by the shareholders (see Section B.6). Bondholders receive the time-dependent coupon $C_{j, t}^{F}$ as long as the firm does not default. In the event of default, bondholders are entitled to the after-tax cash flows of the unlevered firm, $U_{i j, t}$, net of a fraction $\eta \in(0,1)$ that consists of default costs. The flow accruing to the bondholders of firm $i$ located in country $j$, at time $t$, is given by

$$
C F_{i j, t}^{B}=\underbrace{C_{j, t}^{F}\left(1-\mathbf{1}_{\text {def }, i j}\right)}_{\text {Debt coupons before default }}+\underbrace{\left(1-\tau_{j}\right)(1-\eta) U_{i j, t} \mathbf{1}_{\text {def }, i j}}_{\text {Net cash flows after default }},
$$

where the indicator $\mathbf{1}_{\text {def }, i j}$ equals 1 if firm $i$ in country $j$ has defaulted (i.e., $t \geq T_{i j}^{D}$ ), and 0 otherwise.

Equity holders have no claim in default. Before bankruptcy, equity holders of firm $i$ in country $j$ are entitled to the cash flow equal to the sum of after-tax earnings and the constant tax benefits of debt, less the interest payment. It is equal, at time $t$, to

$$
C F_{i j, t}^{E}=\left(1-\tau_{j}\right)\left(U_{i j, t}-C_{j, t}^{F}\right)\left(1-\mathbf{1}_{\mathrm{def}, i j}\right) .
$$

\section{Equity Valuation}

Equity value is determined by the present value of the cash flows entitled to shareholders until bankruptcy. When the Foreign government defaults at time $T^{G}$, the economy is hit by a temporary slowdown that affects firm cash flows. Equity value thus depends on the risk of a sovereign default and is given by (see Internet Appendix G)

$$
E_{i j, t}=\underbrace{\mathbb{E}_{t}\left[\int_{t}^{T^{G}} \frac{\xi_{u}}{\xi_{t}} C F_{i j, u}^{E} d u\right]}_{\text {Before sovereign default }}+\underbrace{\mathbb{E}_{t}\left[\int_{T^{G}}^{T_{i j}^{D}} \frac{\xi_{u}}{\xi_{t}} C F_{i j, u}^{E} d u\right]}_{\text {After sovereign default }} .
$$

The first part of equation (16) accounts for firm revenue growing at the riskneutral rate $\tilde{\theta}_{X, H}$ and cash flows discounted at the risk-free rate $r_{H}$ until sovereign default at time $T^{G}$. Then, once the sovereign has defaulted (the second part), firm revenue temporarily grows at the risk-neutral rate $\tilde{\theta}_{X, L}$, and the cash flows are discounted at the risk-free rate $r_{L}$, until the regime returns to $s=H$. Eventually, equity becomes worthless when the firm defaults at time $T_{i j}^{D} \cdot{ }^{17}$ If a firm is expected to default before the Foreign government defaults, its equity value remains independent of sovereign default risk.

\section{Firm Default Policy}

Shareholders choose the optimal time to default. There is a single optimal default boundary if they decide to default before the Foreign government

\footnotetext{
${ }^{17}$ As long as $t<T_{i j}^{D}$, equity has positive value, and shareholders agree to issue additional equity shares to finance the cash-flow shortage (see Leland (1994)). Cash flows can thus be negative without triggering default. Default is triggered by the shareholders' decision to optimally cease injecting funds into the firm.
} 
defaults, whereas there are two boundaries (i.e., one per state $s$ ) if they default after the Foreign government defaults. The decision to default before or after the Foreign government defaults maximizes the value of equity at time $t=0$ (see Internet Appendix H).

The optimal default boundaries increase exponentially with time because they are linear in the debt coupon $C_{j, t}^{F}$ and the level of operating costs $I_{i j, t}$. However, when scaling the model by the expected growth in firm revenue $g_{t}$, the problem can be solved in the case of constant default boundaries, as noted by Fischer, Heinkel, and Zechner (1989), Leland (1994), and Strebulaev (2007). Internet Appendix F provides details on this approach, which relates to that of Ju, Parrino, Poteshman, and Weisbach (2005).

\section{Firm Entry}

A firm in default is reorganized. Its size is reduced by the default costs and thus equals a fraction $(1-\eta)$ of the former firm. In addition, a new firm immediately enters the market to compensate for the loss in output, which equals a fraction $\eta$ of the former firm's production. The debt coupon levels of the reorganized and new firms are $(1-\eta) C_{j, t}^{F}$ and $\eta C_{j, t}^{F}$, respectively, and the corresponding operating costs are $(1-\eta) v I_{i j, t}$ and $\eta v I_{i j, t}$. These firms exhibit reduced operating costs (i.e., $v<1$ ), thus ensuring that default does not immediately reoccur. The scaling parameter $v$ is determined such that the reorganized and new firms begin with the same default probability as that of the initial firm at $t=0$.

\section{Governments}

This section presents the level of fiscal revenue, describes the Foreign government's preferences, and discusses the government's default policy.

\section{Fiscal Revenue}

Governments raise fiscal revenue by taxing corporate earnings and household income. The level of fiscal revenue in country $j$, denoted $F R_{j, t}$, is given by (see Internet Appendix J.1)

$$
\begin{aligned}
F R_{j, t}= & \underbrace{\int \tau_{j}\left(P_{j, t} X_{i j, t}-I_{i j, t}-C_{j, t}^{F}\right)\left(1-\mathbf{1}_{\text {def }, i j}\right) d G\left(I_{j}\right)}_{\text {Corporate taxes from firms alive }} \\
& +\int[\underbrace{\tau_{j}(1-\eta)\left(P_{j, t} X_{i j, t}-v I_{i j, t}-C_{j, t}^{F}\right)}_{\text {Taxes from reorganized firms }} \\
& +\underbrace{\tau_{j} \eta\left(P_{j, t} X_{i j, t}-v I_{i j, t}-C_{j, t}^{F}\right)}_{\text {Taxes from new firm entry }}] \mathbf{1}_{\text {def }, i j} d G\left(I_{j}\right) \\
& +\underbrace{\int \tau_{j} I_{i j, t}\left(1-\mathbf{1}_{\text {def }, i j}\right) d G\left(I_{j}\right)}_{\text {Labor taxes from firms alive }}+\underbrace{\int \tau_{j} v I_{i j, t} \mathbf{1}_{\text {def }, i j} d G\left(I_{j}\right)}_{\text {Labor taxes after firm defaults }} \\
= & \tau_{j} \int\left[P_{j, t} X_{i j, t}-C_{j, t}^{F}\right] d G\left(I_{j}\right),
\end{aligned}
$$


which implies that firm default costs $\eta$ have no effect on the level of fiscal revenue. On the one hand, firms in default pay less in taxes because the default costs reduce the level of earnings. On the other hand, new firms enter the market to maintain the same level of output and compensate for the reduction in corporate taxes from the bankrupt firms.

Governments use their fiscal revenue to service an infinite-maturity debt contract, characterized by a time-increasing debt coupon $C_{j, t} \equiv g_{t} C_{j, 0}$. The continuous debt issuance allows a target indebtedness level to be maintained over the long run. The government's budget is balanced at each point in time, and the excess fiscal revenues are redistributed to the country's representative consumer (see Internet Appendix J.2), following Aguiar and Amador (2011).

When evaluating the present value of future fiscal revenue, the government is subject to political considerations. It is expected to assign a relatively larger weight to early flows because of term limits and reelection risk. Following this intuition, Aguiar and Amador (2011) show that a government's impatience decreases with the political survival hazard rate and increases with the benefits from remaining in power. Hence, I assume that the government has a preference for time $\beta_{g}$ that exceeds the real risk-free rate. ${ }^{18}$ In comparison, classical models based on Ramsey (1927) and Lucas and Stokey (1983) typically abstract from the potential conflicts between the government and the governed (i.e., the consumers). ${ }^{19}$

\section{Gains from and Costs of Sovereign Default}

The Foreign government strategically defaults on its debt obligations at time $T^{G}$. In default, the terms of the debt contract are restructured, and the debt coupon payment $C_{f, t}$ is reduced by a fraction $\phi \in(0,1)$. The benefits of debt relief give the Foreign government the incentive to default. However, default is costly because it temporarily reduces economic growth (from $\theta_{f, H}$ to $\theta_{f, L}$ ) and thus the level of future fiscal revenue. In addition, the flight-to-quality response to the economic slowdown induces a temporary decrease in the equilibrium interest rate from $r_{H}$ to $r_{L}$, which raises the present value of future debt payments. Both effects constitute the government's motivation for avoiding default. This trade-off between the gains from and the costs of default determines the level of fiscal revenue at which it becomes optimal to default, as noted by Andrade (2009) and Jeanneret (2015). ${ }^{20}$

\footnotetext{
${ }^{18}$ This assumption is shared with Aguiar, Amador, and Gopinath (2009), Aguiar and Amador (2011), Acharya and Rajan (2013), and Aguiar, Amador, Farhi, and Gopinath (2014). A higher impatience level lowers the present value of the default costs, raises the incentive to default, and thus increases the default probability for a given indebtedness level and tax rate. Yet the present model does not require any impatience to generate default.

${ }^{19}$ Moreover, Ramsey (1927) and Lucas and Stokey (1983) analyze the optimal fiscal policy, which is assumed to be exogenous in the paper, whereas the present model focuses on the optimal default policy. However, tax revenue within the model corresponds to the optimal ad valorem (i.e., sales) tax rate on consumption in the Ramsey problem. Indeed, the government levies taxes on firm profits, computed as sales minus operating costs from hiring labor, and from labor income. Further, in the Ramsey tradition, the government's policy is chosen at time 0 , rather than sequentially.

${ }^{20}$ Defaulting is a relevant choice because the government cannot monetize debt in a real environment. In addition, it is assumed that the government will not increase the tax rate during a recession to avoid default. A rise in taxes is difficult to implement in practice and, moreover, inconsistent with the
} 


\section{Government Default Policy}

The government selects the default policy that maximizes its sovereign wealth, which is defined as the present value of future fiscal revenue net of future debt payments. Sovereign wealth in the Foreign country, denoted $S W_{t}$, is equal to (see Internet Appendix J.4)

$$
S W_{t}=\underbrace{\mathbb{E}_{t}^{\mathbb{Q}}\left[\int_{t}^{\infty} F R_{f, u} e^{-\beta_{g}(u-t)} d u\right]}_{\text {Discounted fiscal revenues }}-\underbrace{D_{t}}_{\text {Debt value }},
$$

where the first part captures the present value of fiscal revenue $F R_{f, t}$, and the second part is the value of sovereign debt, denoted $D_{t}$ and given by (see Internet Appendix J.3)

$$
D_{t}=\underbrace{\mathbb{E}_{t}\left[\int_{t}^{T^{G}} \frac{\xi_{u}}{\xi_{t}} C_{f, t} d u\right]}_{\text {Debt service before default }}+\underbrace{\mathbb{E}_{t}\left[\int_{T^{G}}^{\infty} \frac{\xi_{u}}{\xi_{t}}(1-\phi) C_{f, t} d u\right]}_{\text {Debt service after default }},
$$

where $\phi C_{f, t}$ represents the loss to debtholders in sovereign default.

The optimal default boundary maximizes sovereign wealth $S W_{t}$ at time $t=0$ subject to the usual smooth-pasting condition (see Internet Appendix J.4). The default policy determines both the risk-neutral and the physical probabilities of sovereign default. The model thus makes it possible to endogenously link unobservable risk-neutral default probabilities to actual default probabilities via the market price of consumption risk (see Internet Appendix J.5). Default occurs during an economic downturn, in line with the evidence of Reinhart and Rogoff (2009) and Mendoza and Yue (2012).

\section{Market Completeness and Financial Assets}

The model implies that all financial securities are contingent claims to aggregate output $X_{t}$ and thus depend on the same risk factors. This result has several implications. First, financial markets are complete, as there are more assets than sources of shocks within the model. Specifically, beyond equity, any additional asset (e.g., sovereign debt) becomes redundant, as highlighted by Zapatero (1995). Second, investors do not have additional benefits in choosing their international investments. This feature is shared with Helpman and Razin (1978), Cole and Obstfeld (1991), and Zapatero (1995). Therefore, investment in domestic assets only (i.e., pure home bias) is a feasible portfolio choice in equilibrium..$^{21}$ Finally, the model is in line with the global capital asset pricing model

fiscal policy observed in developed economies, which is typically acyclical or countercyclical (i.e., a low tax rate in bad times).

${ }^{21}$ Although it is not the goal of this paper to analyze each country's optimal portfolio, the exact asset allocation remains indeterminate in such an equilibrium. Pavlova and Rigobon (2007) show, in the absence of default policies, that introducing demand shocks helps determine investors' allocation across countries. Berrada, Hugonnier, and Rindisbacher (2007) provide details on the existence of optimal portfolio equilibria for different classes of preferences. 
(CAPM), suggesting that international stock returns depend on a common global source of risk, which is here driven by aggregate output. ${ }^{22}$

\section{Data and Calibration}

This section describes the data and calibration of the model. Hereafter, the United States represents the Domestic country, and Europe represents the Foreign country. Europe consists of the 18 countries that belonged to the euro area as of Dec. 2013.

The model calibration depends on two sets of parameters. Section III.A first discusses the choice of the parameters that are either directly observable in the data (e.g., dynamics of production, relative size of countries, tax rates) or the values of which follow the existing literature (e.g., consumer preference for time, bankruptcy costs, economic costs of sovereign default, sovereign debt haircut in default, crisis duration). Then, Section III.B discusses the parameters related to the level of corporate debt, the distribution of operating costs, the Foreign government's debt level, and the government's preference for time. These parameter values are calibrated such that the model matches a set of key empirical moments in the data.

\section{A. Economic Environment}

The relative size of countries is given by the weight of Domestic production in world output, $\alpha$, which is equal to 0.54 . This weight is computed as the ratio of U.S. GDP to the sum of U.S. and euro area GDPs over the 1991-2013 period. GDP data are in dollars and 2005 constant prices for the United States and in euros and current prices for the euro area. All series are converted to 2005 constant dollars with the euro/dollar exchange rate and the GDP deflator index for the euro area. These data are yearly and come from Datastream.

The empirical counterparts of output are the levels of industrial production in the United States and Europe, denoted $X_{d, t}$ and $X_{f, t}$, respectively. The data are monthly, span the period Jan. 1991-Dec. 2013, and come from Datastream. The dynamics of output are given by the (annualized) mean and standard deviation of industrial production growth rates. The Domestic (Foreign) country has a mean growth rate $\theta_{d}\left(\theta_{f, H}\right)$ of $2.23 \%(0.60 \%)$ and a volatility $\sigma_{d}\left(\sigma_{f}\right)$ of $2.29 \%(3.39 \%)$. The correlation between Domestic and Foreign output growth $\rho$ is set to the correlation between U.S. and European industrial production growth, which equals 0.31 . These data imply a volatility of aggregate output $\sigma_{X}$ equal to $2.27 \%$. Aggregate output is smoother than each country's output because the real exchange rate adjusts to absorb international economic shocks.

In the event of a sovereign default crisis, the expected economic contraction $\Delta \theta$ is set to $5 \%$, which is equal to the average decline in GDP observed for 23 default events over the period 1977-2009 (see Mendoza and Yue (2012)). The aggregate output growth rate $\theta_{X, s}$ is thus equal to $1.47 \%$ in the high state $(s=H)$ and to $-0.83 \%$ during the sovereign default crisis $(s=L)$, and the equilibrium real

\footnotetext{
${ }^{22} \mathrm{~A}$ natural implication is comovement in international equity markets, which is documented by Karolyi and Stulz (1996), Forbes and Rigobon (2002), Bae et al. (2003), Hartmann, Straetmans, and de Vries (2004), and Andersen, Bollerslev, Diebold, and Vega (2007), among others.
} 
risk-free interest rate $r_{s}$ is equal to $3.42 \%$ and $1.12 \%$ in the two states, respectively. The probability of exiting the crisis state $\lambda_{L H}$ is set to 0.4 such that the default period lasts on average 2.5 years, as noted by Aguiar and Gopinath (2006) and Borri and Verdelhan (2012).

The Domestic corporate tax rate $\tau_{d}$ is equal to $35 \%$, as reported by Graham (2006), whereas the Foreign tax rate $\tau_{f}$ equals $30 \%$, which is the average marginal corporate tax rate in the euro zone, using data from the Web site of the Organisation for Economic Co-operation and Development (OECD). The household rate of time preference $\beta$ is set at $2 \%$, as noted by Cole and Obstfeld (1991), and firm default costs $\eta$ are equal to $40 \%$ of firm asset value at the time of default, following Hackbarth et al. (2006). Finally, the expected loss to debtholders upon default $\phi$ equals $60 \%$, which is a market convention for the quotation of sovereign credit default swap (CDS) contracts. All parameter values are reported in Table 1.

\section{TABLE 1}

Parameter Choices

Table 1 reports the calibrated parameters of the model. Output in Europe consists of aggregate industrial production (IP) for the 18 European countries that belonged to the euro area (EU-18) over the period Jan. 1991-Dec. 2013. All variables are annualized when applicable.

\begin{tabular}{|c|c|c|c|}
\hline Variable & Notation & Value & Source \\
\hline \multicolumn{4}{|c|}{$\underline{\text { Panel A. Preferences and Common Characteristics }}$} \\
\hline Household time preference & $\beta$ & 0.02 & Cole and Obstfeld (1991) \\
\hline Weight of Domestic good in world basket & $\alpha$ & 0.54 & $\mathrm{GDP}_{\mathrm{US}} / \mathrm{GDP}_{\mathrm{EU}}+\mathrm{GDP}_{\mathrm{US}}$ over 1991-2013 (data) \\
\hline Correlation of output growth & $\rho$ & 0.31 & Correlation U.S. and EU-18 IP (data) \\
\hline Firm default costs & $\eta$ & 0.4 & Hackbarth et al. (2006) \\
\hline Sovereign debt reduction in default & $\phi$ & 0.6 & $\begin{array}{l}\text { International Swaps and Derivatives Association } \\
\text { (ISDA) convention in credit markets }\end{array}$ \\
\hline Growth contraction in sovereign default & $\Delta \theta$ & 0.05 & Mendoza and Yue (2012) \\
\hline Probability of ending the default crisis & $\lambda_{L H}$ & 0.4 & Aguiar and Gopinath (2006) \\
\hline \multicolumn{4}{|l|}{ Panel B. Domestic Country (United States) } \\
\hline Growth rate (\%) & $\theta_{d}$ & 2.23 & Growth rate of U.S. IP (data) \\
\hline Volatility (\%) & $\sigma_{d}$ & 2.29 & Volatility of U.S. IP (data) \\
\hline Corporate tax rate & $\tau_{d}$ & 0.35 & Graham (2006) \\
\hline Initial level of production & $X_{d, 0}$ & 1 & Normalization \\
\hline Firm operating costs (initial level) & $l_{i d, 0}$ & & $\begin{array}{l}\text { Lognormally distributed with mean } I_{d, 0} \\
\text { (see Table 2) and volatility of } 0.3\end{array}$ \\
\hline \multicolumn{4}{|l|}{ Panel C. Foreign Country (Europe) } \\
\hline Growth rate (\%) & $\theta_{f, H}$ & 0.6 & Growth rate of EU-18 IP (data) \\
\hline Volatility $(\%)$ & $\sigma_{f}$ & 3.39 & Volatility of EU-18 IP (data) \\
\hline Corporate tax rate & $\tau_{f}$ & 0.3 & Average tax rate in EU-18 (OECD) \\
\hline Initial level of production & $X_{f, 0}$ & 1 & Normalization \\
\hline Firm operating costs (initial level) & $l_{i f, 0}$ & & $\begin{array}{l}\text { Lognormally distributed with mean } I_{f, 0} \\
\text { (see Table 2) and volatility of } 0.3\end{array}$ \\
\hline
\end{tabular}

\section{B. Structural Calibration}

This section describes the calibration of the remaining parameters. They include each country's corporate debt coupon $C_{j, 0}^{F}$ and average operating cost $I_{j, 0}$. Firm $i$ 's operating cost level $I_{i j, 0}$ in country $j$ is drawn from a lognormal distribution $G\left(I_{j}\right)$ with mean $I_{j, 0}$ and volatility 0.3 (see Section IV.A for further details). The remaining variables to calibrate are the Foreign government's debt coupon $C_{f, 0}$ and preference for time $\beta_{g}$.

These parameters are estimated such that the model matches the following set of moments: i) the volatility of U.S. and European equity returns, computed 
as the standard deviation of monthly returns on the S\&P 500 index and the Euro Stoxx 600 ex-U.K. index measured in U.S. dollars, respectively. The estimates are $15.8 \%$ in the United States and $20.1 \%$ in Europe over the period 1991-2013; ii) the level of financial leverage, computed as the average market debt-to-asset ratio for U.S. and European nonfinancial firms. ${ }^{23}$ Using data from Capital IQ and Bloomberg on 5,229 U.S. firms and 4,310 European firms, the mean leverage for the United States and Europe is $18.8 \%$ and $26.9 \%$, respectively; ${ }^{24}$ iii) the average debt-to-GDP ratio of the euro area, which equals 71\% over the period 1991-2013, using data from the Web site of the European Central Bank (ECB); and, finally, iv) the 10-year sovereign default probability, equal to $6 \%$, which is computed as the 10-year issuer-weighted average cumulative default rate for all sovereign issuers over the period 1983-2012 (Moody's (2012)).

The model counterparts of these moments are the average equity return volatility and financial leverage, which are computed over 500 value-weighted heterogeneous firms in each country; the Foreign government's debt-to-output ratio; and the 10-year sovereign default probability. The calibration successfully matches the empirical moments.

Table 2 reports the parameter values, which are all statistically significant. The corporate debt coupons, $C_{d, 0}^{F}$ and $C_{f, 0}^{F}$, are equal to $2.68 \%$ and $3.81 \%$ of firm revenue in the United States and Europe, respectively. Firms have operating cost $I_{i j, 0}$, measured as a percentage of firm revenue, drawn from a lognormal distribution with mean equal to $86.3 \%$ in the United States and $89.1 \%$ in Europe. The cost difference across countries suggests that U.S. firms are more productive than their European counterparts, in line with the data. ${ }^{25}$

Finally, the level of the sovereign debt coupon $C_{f, 0}$ is equal to $1.44 \%$ of output value, and the estimate of the government's preference for time $\beta_{g}$ is $7.25 \%$. This parameter value exceeds the risk-free rate, thus confirming that governments display some impatience (see Aguiar and Amador (2011), Acharya and Rajan (2013), and Aguiar et al. (2009), (2014)).

\section{Theoretical Analysis}

This section examines the impact of sovereign credit risk on equity prices across countries. First, a static analysis explores the channels through which the effect occurs and provides quantitative predictions according to economic conditions. Then, the model is applied to the data to investigate how the sensitivity of the U.S. equity market to European sovereign credit risk varies over the period 1991-2013.

\footnotetext{
${ }^{23}$ Following Rajan and Zingales (1995), I eliminate financial firms such as banks and insurance companies from the sample because their debt-like liabilities are not strictly comparable to the debt issued by nonfinancial firms.

${ }^{24}$ The data are available on Aswath Damodaran's Web site (http://pages.stern.nyu.edu/ adamodar/).

${ }^{25}$ Van Ark, O'Mahony, and Timmer (2008) report that the average level of productivity in 15 European countries relative to the United States, computed from the level of GDP per hour worked, is equal to $98.3 \%$ in 1995 and $90.3 \%$ in 2004 . Hence, U.S. firms appear to be approximately $5 \%$ more productive than European firms, on average.
} 
TABLE 2

\section{Model Calibration}

Table 2 reports the calibration of the model. The calibrated parameters reported in Panel B are estimated to match the set of moment conditions presented in Panel A. The heteroskedasticity-consistent standard errors are corrected for serial correlation using Newey and West's (1987) nonparametric variance covariance estimator with 6 lags. The theoretical moments are computed over the period from Jan. 1991-Dec. 2013. All variables are annualized when applicable.

Panel A. Target Moments

\begin{tabular}{|c|c|c|c|c|c|}
\hline Theoretical Moment & Notation & Targeted Value & Data & & Source \\
\hline Domestic equity return volatility & $\sigma_{E_{d}}$ & 0.158 & $\begin{array}{l}\text { Volatility of S\&P } 500 \\
\text { returns (1991-2013, } \\
\text { monthly data) }\end{array}$ & & $\begin{array}{l}\text { Author's } \\
\text { calculation }\end{array}$ \\
\hline Foreign equity return volatility & $\sigma_{E_{f}}$ & 0.201 & $\begin{array}{l}\text { Volatility of Euro Stoxx } 600 \\
\text { ex-U.K. returns } \\
\text { (1991-2013, monthly } \\
\text { USD data) }\end{array}$ & & $\begin{array}{l}\text { Author's } \\
\text { calculation }\end{array}$ \\
\hline Domestic financial leverage & $D_{d} / V_{d}$ & 0.188 & $\begin{array}{l}\text { Mean financial leverage of } \\
\text { U.S. firms in } 2010\end{array}$ & & \multirow[t]{2}{*}{$\begin{array}{l}\text { Author's } \\
\text { calculation with } \\
\text { Damodaran's } \\
\text { data }\end{array}$} \\
\hline Foreign financial leverage & $D_{f} / V_{f}$ & 0.269 & $\begin{array}{l}\text { Mean financial leverage of } \\
\text { EU firms in } 2010\end{array}$ & & \\
\hline $\begin{array}{l}\text { Government debt-to-output } \\
\text { ratio (face value) }\end{array}$ & $\left(C / r_{H}\right) / X$ & 0.71 & $\begin{array}{l}\text { Average government } \\
\text { debt-to-GDP ratio in } \\
\text { EU-18 countries }\end{array}$ & & ECB data \\
\hline $\begin{array}{l}\text { 10-year probability of sovereign } \\
\text { default }\end{array}$ & $\mathbb{P}$ & 0.06 & $\begin{array}{l}\text { 10-year cumulative default } \\
\text { rate of sovereign issuers } \\
\text { (1983-2012) }\end{array}$ & & Moody's (2012) \\
\hline \multicolumn{6}{|l|}{ Panel B. Calibrated Parameters } \\
\hline \multicolumn{2}{|l|}{ Parameter } & Notation & Estimate & Std. Err. & $t$-Stat. \\
\hline \multicolumn{2}{|c|}{ Domestic firm debt coupon (initial level) } & $C_{d, 0}^{F}$ & 0.02681 & 0.00019 & 143.76 \\
\hline \multicolumn{2}{|c|}{$\begin{array}{l}\text { Foreign firm debt coupon (initial level) } \\
\text { Domestic firm operating costs (mean, initial level) } \\
\text { Foreign firm operating costs (mean, initial level) } \\
\text { Sovereign debt coupon (initial level) } \\
\text { Government time preference }\end{array}$} & $\begin{array}{l}C_{f, 0}^{F} \\
l_{d, 0}^{F} \\
l_{f, 0} \\
C_{0} \\
\beta_{g}\end{array}$ & $\begin{array}{l}0.03810 \\
0.86253 \\
0.89104 \\
0.01444 \\
0.07253\end{array}$ & $\begin{array}{l}0.00049 \\
0.01072 \\
0.01075 \\
0.00014 \\
0.00052\end{array}$ & $\begin{array}{r}76.49 \\
80.43 \\
82.85 \\
100.36 \\
138.88\end{array}$ \\
\hline
\end{tabular}

\section{A. Distribution of Firms and Heterogeneity}

Before analyzing predictions at the market level, I first illustrate how firms differ within and across countries. Firm heterogeneity implies that each firm has a specific default policy and risk level. To demonstrate this, Figure 2 displays the optimal default boundary and the level of equity return volatility with respect to level of operating costs. Firms with high operating costs tend to default early (i.e., have a high default boundary) and exhibit high return volatility. As a consequence, these firms are highly levered and expected to default before a sovereign crisis affects Europe. In contrast, highly productive firms are less risky and thus expected to survive a sovereign default crisis. For some firms with intermediate levels of productivity, shareholders find it optimal to default at the same time as the sovereign defaults. Hence, the model predicts default clustering during a sovereign default crisis. Finally, Figure 2 illustrates the distribution of firms within each country.

\section{B. Model Predictions by Economic Conditions}

I now consider the calibrated economy to analyze the risk of sovereign default, value international equity prices, and discuss the level of equity return 
FIGURE 2

Firm Heterogeneity, Default Policy, and Equity Valuation

Graphs A and B of Figure 2 show the firm default policies in the United States (Graph A) and Europe (Graph B) by the level of operating costs, which are compared with the sovereign default policy. Firm and sovereign default boundaries are reported for the initial date as a fraction of firm revenue and output value, respectively. Each economy consists of 500 firms that vary in their level of productivity, as measured by operating costs as a percentage of firm revenue. Graph $\mathrm{C}$ illustrates the distribution of firm heterogeneity, and Graph D exhibits predictions for the level of equity return volatility at the firm level. The parameters of the model are those reported in Tables 1 and 2.
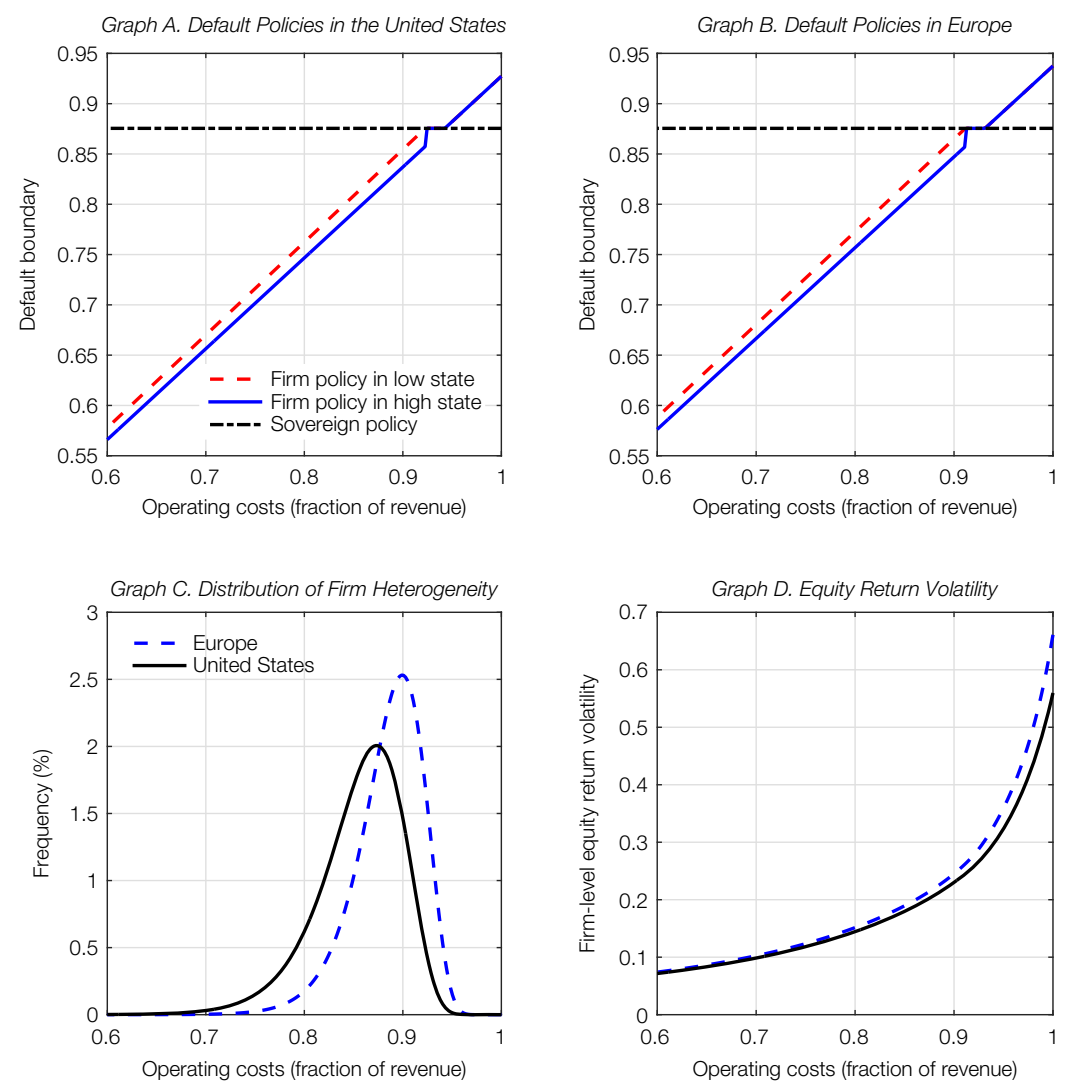

volatility. To investigate how the model predictions vary with the business cycle, consider three scenarios: normal economic conditions $(X=1)$, economic growth $(X=1.05)$, and economic downturn $(X=0.95)$. Table 3 reports the results.

\section{Government Default Risk and Indebtedness}

The model predicts that the probability of sovereign default in Europe rises when economic conditions deteriorate because weak fiscal revenue increases the government's incentive to benefit from debt relief. Panel A of Table 3 indicates that the 10-year probability of a default crisis in Europe is negligible in periods of economic growth $(1.1 \%)$ but becomes important during a downturn $(25.5 \%)$. The corresponding risk-neutral probabilities are $1.4 \%$ and $27.7 \%$. Government indebtedness, measured by the debt-to-output ratio, is countercyclical when computed 
TABLE 3

Model Predictions over the Business Cycle

Table 3 illustrates the model predictions for different economic conditions. Panel A reports predictions on sovereign indebtedness and creditworthiness in Europe. Panel B displays predictions for the U.S. equity market, which consists of 500 value-weighted heterogeneous levered firms. The panel reports the level of equity return volatility, equity price, and financial leverage ratio when the expected crisis duration is either 1 year $\left(\lambda_{L H}=1\right)$ or 2.5 years $\left(\lambda_{L H}=0.4\right)$. Panel $C$ provides hypothetical predictions for the U.S. equity market in the absence of financial leverage. Panels B and $\mathrm{C}$ present results with and without sovereign credit risk. All variables are annualized. The parameters of the model are those reported in Tables 1 and 2.

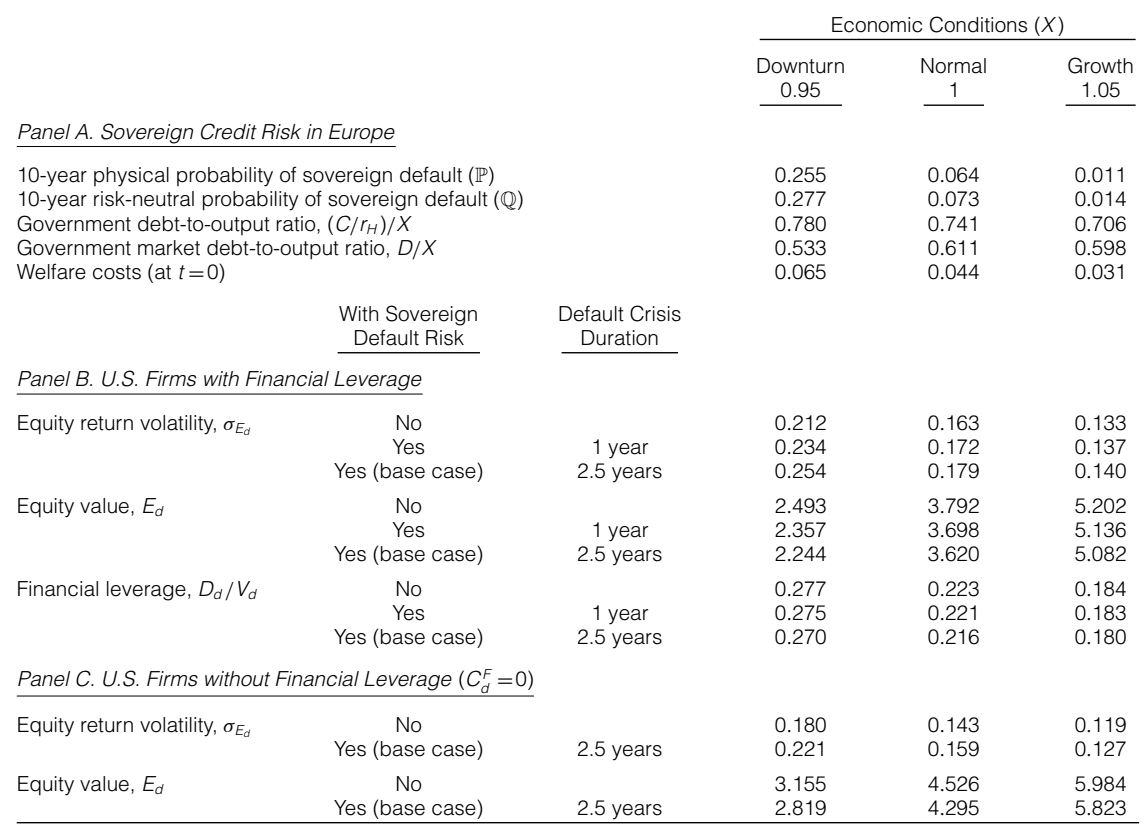

with the face value of debt but cyclical when computed with the market value. Default risk drives the difference between the two values.

\section{Equity Prices and the Business Cycle}

The analysis now turns to the U.S. equity market, which consists of 500 heterogeneous levered firms weighted by market capitalization. The model predicts that equity market prices are cyclical and that the level of equity return volatility is countercyclical (see Panel B of Table 3), in line with empirical evidence. ${ }^{26}$ In the baseline calibration, the predicted level of market volatility is $14 \%$ in boom periods and $17.9 \%$ under stable economic conditions, and it equals $25.4 \%$ in downturns. Financial leverage, which is computed as the debt-to-asset ratio, also rises during adverse economic conditions. The ratio equals $18 \%, 21.6 \%$, and $27 \%$ under these scenarios, respectively.

\footnotetext{
${ }^{26}$ See, for instance, Schwert (1989), Forbes and Rigobon (2002), Bae et al. (2003), Engle and Rangel (2008), and Engle et al. (2013), among others.
} 
The countercyclical nature of equity return volatility arises from two features of the model. First, operating costs generate an operating leverage that raises the volatility of firm earnings and thus the volatility of equity returns (see Lev (1974)). Panel $\mathrm{C}$ of Table 3 indeed shows that equity return volatility is countercyclical even in the absence of financial leverage and sovereign credit risk.

Second, firm default probability rises in periods of distress, thereby lowering the value of equity relative to the value of debt. The increase in financial leverage raises the volatility of equity returns (see Black (1976), Christie (1982)). Accounting for firm leverage makes it possible to generate levels of equity return volatility that better compare with the data. ${ }^{27}$

\section{Role of Sovereign Credit Risk}

The model suggests that the risk of sovereign default amplifies the decline in equity prices and the increase in equity return volatility when economic conditions deteriorate (see Panel B of Table 3). Sovereign default risk affects firms internationally through two complementary channels. First, an economic slowdown in Europe reduces European firm revenue directly and U.S. firm revenue indirectly, through an adjustment of the real exchange rate. This is the international risk-sharing channel. Second, this slowdown triggers an incentive to rebalance portfolios toward the risk-free asset, which arises from the flight to safety. The lower risk-free rate raises the value of debt and depresses equity prices in both countries. In addition, shareholders select a higher default boundary during a sovereign default crisis, thus further increasing the probability of bankruptcy. ${ }^{28}$

The difference in equity value in the absence and presence of sovereign default risk corresponds to a "sovereign default risk discount" on equity prices. Using the results from Panel B of Table 3, this discount in the U.S. equity market equals $1.42 \%$ in good times and $7.64 \%$ in downturns. The difference in equity return volatility with and without sovereign default risk is $0.7 \%$ in periods of economic growth and $4.2 \%$ in downturns. ${ }^{29}$ Therefore, the risk of an economic slowdown due to a sovereign default affects the U.S. equity market particularly strongly in periods of economic decline, when it is the least desirable for investors.

\section{Size of the Crisis Country}

The model predictions suggest that the risk of a European debt crisis has a strong effect on the U.S. stock market because the euro zone represents a sizable fraction of the world economy (46\%; see Table 1). A contraction in European output growth rate by $5 \%$ is then associated with a reduction in the U.S. firm revenue growth rate of $2.3 \%$ (i.e., $0.46 \times 5 \%$ ).

\footnotetext{
${ }^{27}$ Alternative explanations for the countercyclicality in equity return volatility include those of Bansal and Yaron (2004), who assume that consumption volatility rises during recessions, or models of limited equity market participation, such as that by Basak and Cuoco (1998).

${ }^{28}$ The default boundary is indeed higher for state $s=L$ than for state $s=H$ (see Figure 2), as noted by Bhamra et al. (2010a), (2010b).

${ }^{29}$ These effects may be regarded as the upper bounds of the true effects because the model assumes that output growth would decline only in the case of a sovereign default. However, the calibration is set to match the level of financial leverage and equity return volatility in the data. Introducing an additional source of risk, such as stochastic regimes (e.g., Chen (2010), Bhamra et al. (2010a), (2010b)) or longrun risk (e.g., Bansal and Yaron (2004)), would thus further complicate the model without changing the main message of this paper.
} 
The contraction in output growth in the event of sovereign default is thus shared internationally but not equally across countries. The model predicts that the larger the country in crisis relative to world output (i.e., lower $\alpha$ ), the greater the impact of an economic slowdown on international firms. Thus, a default crisis in a small open economy would have a much smaller impact on U.S. stocks. To put this in perspective, the predicted expected decline in the U.S. firm revenue growth rate due to a sovereign default in Argentina (Russia) in 2001 (1998) would only be $0.16 \%(0.22 \%) .{ }^{30}$ This is an order of magnitude smaller than for a crisis in Europe.

\section{Severity of a Sovereign Default Crisis}

One can expect the effect of sovereign credit risk on equities to be greatest for a long-lasting debt crisis that induces a severe economic slowdown. To verify that intuition, Figure 3 displays the predicted level of U.S. stock market prices and the corresponding volatility for different scenarios: The expected duration of the crisis, $1 / \lambda_{L H}$, varies between 1 and 4 years, and the economic slowdown, $\Delta \theta$, ranges between $0 \%$ and $8 \%$. The results suggest that the risk of a sovereign crisis characterized by a decline in economic growth of $5 \%$ over 1 (4) year(s) reduces today's U.S. equity market prices by $2.48 \%$ (5.65\%). The corresponding increase in equity market volatility is $0.84 \%(1.97 \%)$. Hence, the effect of sovereign default risk on equity valuation strongly depends on the expected severity of the sovereign default crisis.

Notably, Figure 3 suggests that the marginal impact of sovereign default risk on the equity market decreases with the expected length and magnitude of the slowdown. As a debt crisis is expected to be more severe, shareholders choose to default before the crisis occurs. Therefore, the number of firms that depend on sovereign default risk decreases, and the market overall becomes less sensitive to such a risk.

\section{Welfare Costs of a Sovereign Default Crisis}

Thus far, the analysis has focused on the sensitivity of the U.S. equity market to European sovereign credit risk. Yet a sovereign default in Europe is also costly for agents in the euro zone because their expected consumption growth declines during the crisis. Risk-averse consumers prefer a stable consumption growth rate to a path that depends on sovereign default. Hence, the presence of sovereign credit risk generates welfare costs. Following Lucas (1987), I quantify the level of consumption that the representative European consumer would demand to become indifferent between a consumption path without sovereign default risk and the compensated path with a temporarily lower growth rate during the sovereign crisis. The compensation, measured as a fraction of consumption at the time of sovereign default, equals $\Delta \theta /\left(\beta+\lambda_{L H}\right)$ (see Internet Appendix K). The welfare costs thus depend linearly on the magnitude of the economic slowdown during a sovereign default crisis.

Under the baseline calibration, the welfare costs amount to $11.9 \%$ of consumption at the time of sovereign default, which corresponds to $4.4 \%$ in present

\footnotetext{
${ }^{30}$ Using GDP data from the World Bank, the relative size of Argentina (Russia) in early 2001 (1998) is $3.24 \%(4.49 \%)$.
} 
FIGURE 3

Equity Valuation, Welfare Costs, and Severity of the Sovereign Crisis

Graph A of Figure 3 shows the relationship between the U.S. equity market price, which is a value-weighted index of 500 heterogeneous firms, and the expected severity of a sovereign default crisis. Graph B reports the results for the level of equity return volatility. The figure displays various scenarios that differ in the length of the sovereign crisis and the magnitude of the economic slowdown. Graphs C and D report the welfare costs related to sovereign default risk. Welfare costs, which correspond to the fraction of consumption that European consumers require as compensation for bearing the risk of an economic slowdown, are expressed in present value (Graph C) and in the value at the time of sovereign default (Graph D). The parameters of the model are those reported in Tables 1 and 2.

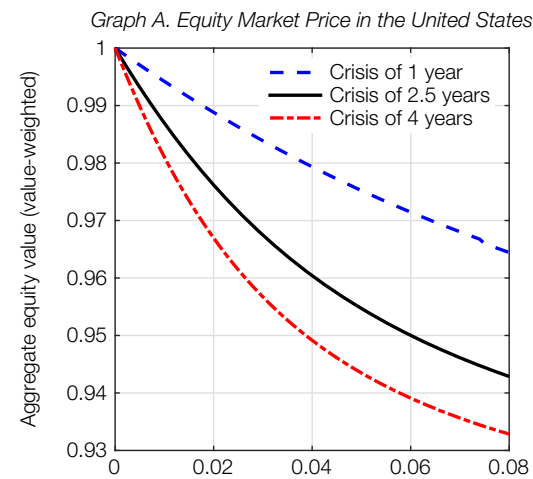

Fall in economic growth during sovereign crisis

Graph C. Welfare Costs in Present Value

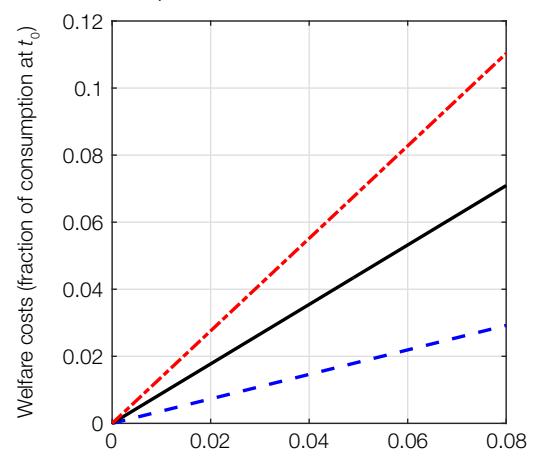

Fall in economic growth during sovereign crisis

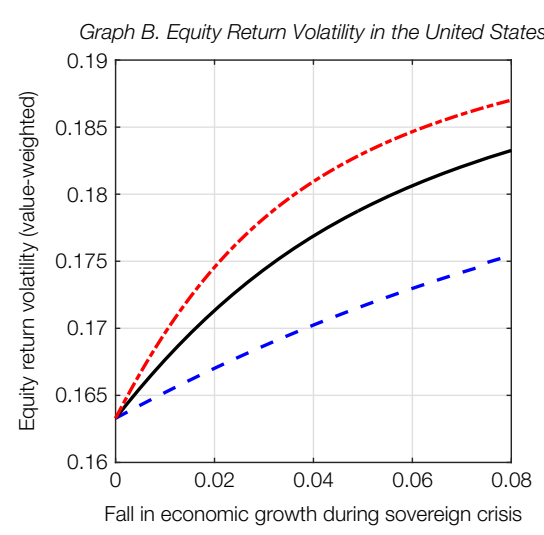

Graph D. Welfare Costs at Time of Sovereign Default

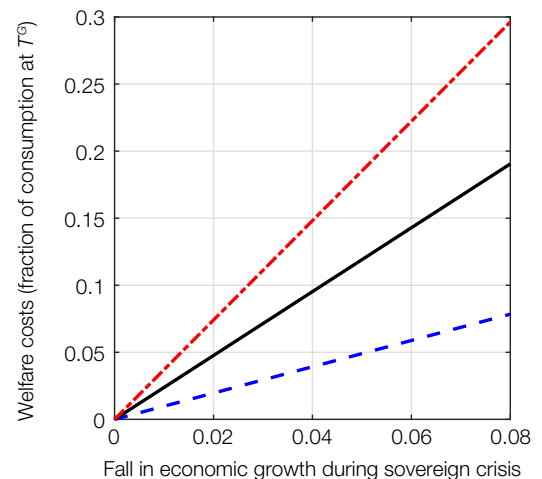

value (see Panel A of Table 3). Figure 3 shows how the compensation level varies with the expected severity of the sovereign default crisis. The welfare costs increase with a greater expected slowdown and with a lower likelihood of exiting the sovereign default state.

\section{Conditional Asset Prices}

This subsection uses monthly industrial production data for Europe and the United States to generate model predictions for the dynamics of equity prices, equity return volatility, and sovereign default risk over the 1991-2013 period. 


\section{U.S. Equity Market}

Graph A of Figure 4 plots the model-implied U.S. equity market price, computed over 500 value-weighted heterogeneous firms. When compared with the dynamics of observed equity prices in the United States (Graph B), measured with the S\&P 500 index, the model fits the data reasonably well over the sample period.

Graph C of Figure 4 displays the reduction in U.S. equity prices due to sovereign default risk, which equals $3.63 \%$ on average. The reduction varies between $0.7 \%$ before the bursting of the technological bubble in 2000 and $18 \%$ at the peak of the U.S. financial turmoil in 2009. The effect of sovereign default risk

FIGURE 4

Model Predictions on U.S. Equity Prices (1991-2013)

Graph A of Figure 4 illustrates the model-implied U.S. equity market price, which is a value-weighted index of 500 heterogeneous firms, with and without sovereign default risk. The difference between the two is displayed in percentage terms in Graph C for different expected crisis durations. As a comparison, Graph B shows the performance of observed U.S. equity market prices, proxied by the S\&P 500 index. Gray areas indicate National Bureau of Economic Research (NBER) recession periods. The input series are monthly industrial production data over the period 1991-2013. The parameters of the model are those reported in Tables 1 and 2.
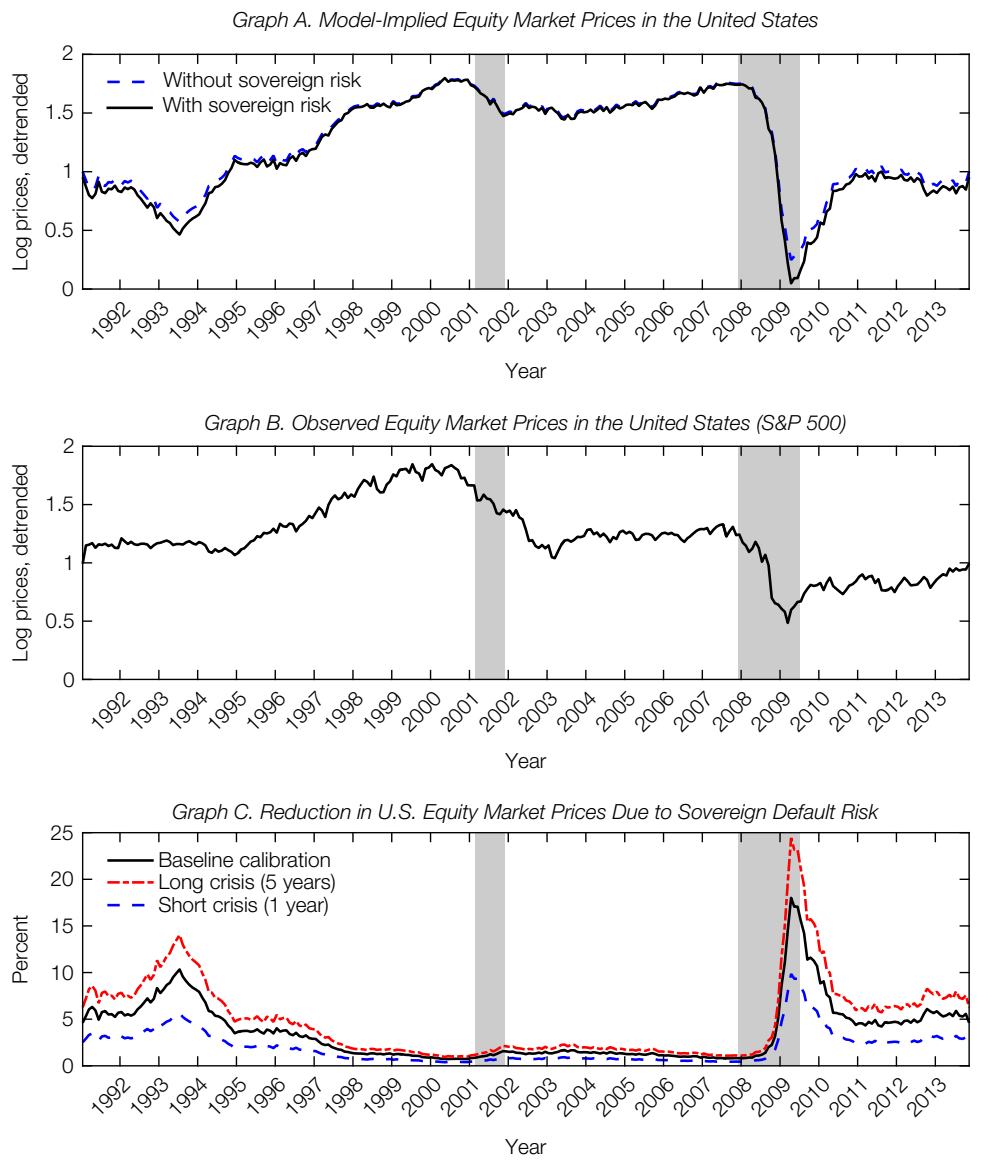
on the U.S. stock market is thus particularly strong in periods of crisis; investors discount the risk of economic slowdown more severely when firms are closer to distress. In addition, when comparing different lengths of the crisis (Graph $\mathrm{C}$ of Figure 4), the model predicts that the expected severity of the crisis raises this discount.

Graph A of Figure 5 illustrates the time-varying level of equity return volatility in the United States, with and without sovereign default risk in Europe. In both cases, the level of equity return volatility is negatively related to global economic output, as displayed in Graph B. The model predicts that the level of equity volatility ranges between $9.85 \%$ and $35.14 \%$. Without sovereign default risk, the

\section{FIGURE 5}

Model Predictions on U.S. Equity Return Volatility and Probability of Sovereign Default in Europe (1991-2013)

Graph A of Figure 5 illustrates the value-weighted level of equity return volatility in the United States, as predicted by the model, with and without sovereign default risk. Graph B exhibits the macroeconomic conditions prevailing in Europe and the United States over the sample period. Graph C shows the 10-year model-implied risk-neutral probability of sovereign default crisis in Europe and the probability of recession in the United States computed with a Markov regime-switching model. Gray areas indicate NBER recession periods. The input series are monthly industrial production data over the period 1991-2013. The parameters of the model are those reported in Tables 1 and 2
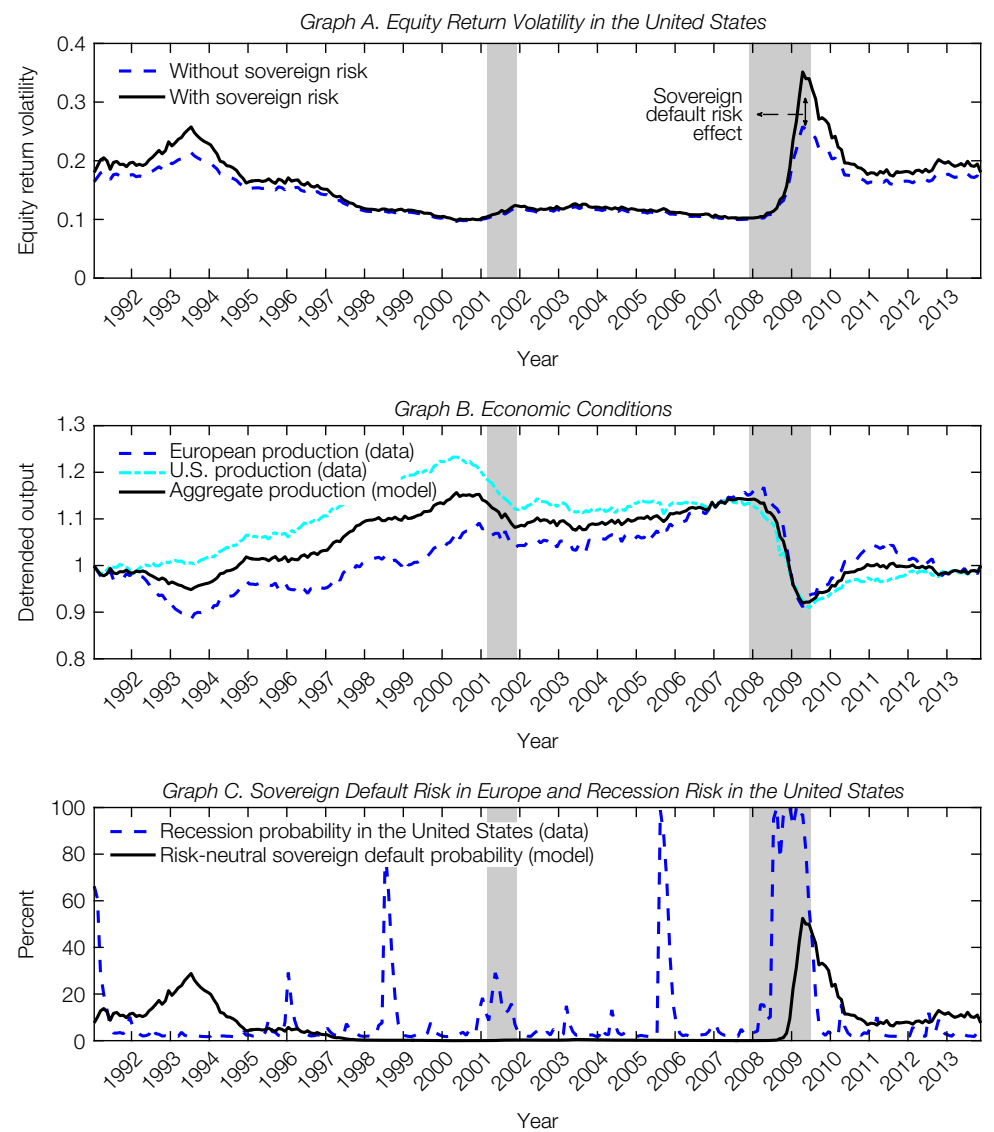
volatility would be reduced by $3.63 \%$ on average, with the reduction varying between $0.19 \%$ in good times and by $9.32 \%$ in bad times. The presence of sovereign default risk thus amplifies the sensitivity of U.S. equity market prices to economic shocks in a countercyclical fashion. Hence, in the absence of sovereign default risk in Europe, U.S. equity market prices would have been higher and less volatile, particularly when financial conditions deteriorate.

\section{Probability of Sovereign Default}

Graph C of Figure 5 illustrates the 10-year model-implied probability of a sovereign default crisis in Europe. The predicted risk of sovereign default is particularly high during the European monetary crisis of 1992-1993 and during the recent financial and sovereign debt crisis of 2008-2011. The model indicates, as early as 2009, that a sovereign default crisis in Europe was likely to occur in the near future; the 10-year (risk-neutral) probability of a crisis reached $50.1 \%(52.5 \%)$. The unconditional 10-year probability remains $6 \%$, as calibrated to Moody's (2012). The model generates not only time variation in default probability but also strong comovement between sovereign default risk and U.S. equity return volatility, in line with the empirical evidence (e.g., Longstaff et al. (2011)).

\section{Sovereign Default Risk versus Recession Risk}

It is important to verify that the model-implied measure of sovereign default risk does not merely capture the risk of a U.S. recession. To this end, Graph C of Figure 5 compares both types of risk. First, NBER recession periods, illustrated with shaded areas, rarely correspond to periods with surges in sovereign credit risk. As an alternative measure, Graph $\mathrm{C}$ reports the probability that the U.S. economy is in bad times, computed with a Markov regime-switching model (see Hamilton (1989)). ${ }^{31}$ High probabilities of being in the bad state poorly coincide with peaks in European sovereign default risk (e.g., European monetary crisis of 1992-1993, U.S. recessions in 1990-1991 and 2001). It is likely that the U.S. economic crisis of 2007-2009 contributed to the rise in European sovereign default risk in subsequent years. However, the probability of sovereign default started to increase only in the middle of the recession period and peaked at the official end of the U.S. crisis. At that time, sovereign credit risk remained high for a few years, whereas the risk of a U.S. crisis quickly faded. The risk of sovereign default in Europe and the risk of recession in the United States thus seem to be separate phenomena, which are expected to affect investors differently. ${ }^{32}$

\section{Structural Estimation}

This section provides a structural test of the model. The goal is to determine whether sovereign default risk in Europe has a statistically significant and negative effect on the valuation of international firms. I begin with a discussion of the

\footnotetext{
${ }^{31}$ This probability is estimated with a Markov switching model with two states for the mean and volatility of the U.S. growth rate, using monthly industrial production in the United States from Jan. 1950-Dec. 2013. Internet Appendix L provides details on the estimation.

${ }^{32}$ Essentially, a recession describes a past contraction in the economy, the end of which is characterized by a recovery in economic activity. In contrast, sovereign default generates an economic slowdown in the near future.
} 
endogenous relationship between sovereign credit risk and equity market prices, describe the estimation methodology that addresses this issue, and then present the results.

\section{A. Endogeneity between Sovereign Credit Risk and Equity Prices}

The main prediction of the model is that sovereign default risk in Europe affects the valuation of international equities and their level of volatility. Empirically testing this prediction is not straightforward because both sovereign credit risk and equity markets tend to respond endogenously to the same economic shocks. Negative economic shocks worsen the fiscal situation in Europe, thus increasing the probability of sovereign default. The same shocks also depress the value of equity, thereby increasing the level of equity return volatility. Hence, comovement may be observed without causality.

The problem is then to disentangle the causal from the endogenous relationship. An econometric analysis regressing U.S. equity return volatility on European sovereign credit spreads, for example, would certainly suggest a strong positive relationship but would not provide any meaningful information on the direction of causality. A second issue is that sovereign credit spreads may include information other than the probability of sovereign default, such as a time-varying risk premium. $^{33}$

This study departs from the regression-based approach and instead proposes a structural estimation of the model that addresses this endogeneity issue. First, the model structurally disentangles the direct effect of sovereign default risk on international equity markets from the comovement that arises due to a common response to economic shocks. Second, the estimation does not require the use of sovereign credit spreads because the model generates the probability of sovereign default directly from the macroeconomic data.

\section{B. Parameters and Moments}

The structural estimation is based on a 2-step GMM estimation. ${ }^{34}$ The main parameters of interest are the expected length of the sovereign default crisis, as measured by $\lambda_{L H}$, and the expected contraction in economic growth at the emergence of such a crisis, as captured by $\Delta \theta$. Additional estimates include the corporate debt coupons in the United States and Europe, $C_{d, 0}^{F}$ and $C_{f, 0}^{F}$, respectively. These estimates are determined to match a set of data moments and modelimplied moments as closely as possible. The moments under consideration are the volatility of equity returns, the level of financial leverage in the United States and Europe, and the 10-year probability of sovereign default, which are described in Section III.B.

Table 4 reports the parameter estimates, asymptotic standard deviations with the Newey and West (1987) correction (6 lags), and the GMM-minimized criterion $\left(\chi^{2}\right)$ value, which indicates the goodness-of-fit of the model.

\footnotetext{
${ }^{33}$ For example, Pan and Singleton (2008), Remolona et al. (2008), and Longstaff et al. (2011) suggest that sovereign credit spreads vary with the volatility risk premium embedded in the optionimplied volatility of the S\&P 500 (VIX).

${ }^{34}$ The procedure tests a set of overidentifying restrictions on a system of moment equations using an optimal weighting matrix. Internet Appendix M provides the details.
} 
TABLE 4

GMM Estimation

Table 4 provides the results of the model estimation using the general method of moments (GMM). Panel A reports the annualized pricing errors between the model-implied moments, which are generated with monthly industrial production data for the United States and the euro area over the period 1991-2013, and the target moments, which are described in Table 2. Panel B presents the parameter estimates, which are the initial corporate debt coupons in the United States and Europe, $C_{d, 0}^{F}$ and $C_{f, 0}^{F}$, respectively; the probability of ending the crisis, $\lambda_{L H}$; and the expected economic contraction upon sovereign default, $\Delta \theta$. The remaining parameters are reported in Table 1. The $\chi^{2}$ statistic in Panel $\mathrm{C}$ (and corresponding $p$-value) jointly tests whether empirical and theoretical moments are equal. The heteroskedasticity-consistent standard errors, presented in parentheses, are corrected for serial correlation using Newey and West's (1987) nonparametric variance covariance estimator with 6 lags. ${ }^{*}$ and ${ }^{* *}$ indicate significance at the $5 \%$ and $1 \%$ levels, respectively.

\begin{tabular}{|c|c|c|c|c|c|}
\hline \multirow{4}{*}{ Panel A. Moment Pricing Errors } & \multicolumn{2}{|c|}{ Main Results } & \multicolumn{3}{|c|}{ Additional Analysis } \\
\hline & \multirow{3}{*}{$\begin{array}{l}\text { Length } \\
\text { of Crisis } \\
1 \\
\end{array}$} & \multirow{3}{*}{$\begin{array}{c}\text { Magnitude } \\
\text { of Crisis } \\
2 \\
\end{array}$} & \multirow{3}{*}{$\begin{array}{c}\text { Single } \\
\text { Firm } \\
3 \\
\end{array}$} & \multirow{3}{*}{$\begin{array}{c}\Delta \theta=0 \\
4 \\
\end{array}$} & \multirow{3}{*}{$\begin{array}{c}\Delta \theta=0 \\
\text { U.S. } \\
\text { Only } \\
5\end{array}$} \\
\hline & & & & & \\
\hline & & & & & \\
\hline $\begin{array}{l}\text { Equity return volatility (United States) } \\
\sigma_{E_{d}, t}-\sigma_{r_{u s}}(\%)\end{array}$ & $\begin{array}{c}-0.044 \\
(0.791)\end{array}$ & $\begin{array}{c}0.049 \\
(0.791)\end{array}$ & $\begin{array}{c}1.307 \\
(0.970)\end{array}$ & $\begin{array}{l}-1.642^{\star \star} \\
(0.559)\end{array}$ & $\begin{array}{c}-1.610^{\star *} \\
(0.558)\end{array}$ \\
\hline $\begin{array}{l}\text { Firm leverage (United States) } \\
\quad\left(D_{d, t} / V_{d, t}\right)-\left(D_{u s} / V_{u s}\right)(\%)\end{array}$ & $\begin{array}{c}0.059 \\
(0.710)\end{array}$ & $\begin{array}{c}0.146 \\
(0.703)\end{array}$ & $\begin{array}{r}1.655^{\star} \\
(0.760)\end{array}$ & $\begin{array}{l}-2.636^{\star \star} \\
(0.717)\end{array}$ & $\begin{array}{c}-2.316^{\star *} \\
(0.698)\end{array}$ \\
\hline $\begin{array}{l}\text { Equity return volatility (Europe) } \\
\sigma_{E_{f}, t}-\sigma_{r e u}(\%)\end{array}$ & $\begin{array}{c}-0.094 \\
(1.101)\end{array}$ & $\begin{array}{c}0.033 \\
(1.105)\end{array}$ & $\begin{array}{c}1.592 \\
(1.341)\end{array}$ & $\begin{array}{r}-1.906^{\star} \\
(0.840)\end{array}$ & \\
\hline $\begin{array}{l}\text { Firm leverage (Europe) } \\
\qquad\left(D_{f, t} / V_{f, t}\right)-\left(D_{e u} / V_{e u}\right)(\%)\end{array}$ & $\begin{array}{c}0.100 \\
(1.031)\end{array}$ & $\begin{array}{c}0.227 \\
(1.019)\end{array}$ & $\begin{array}{r}2.478^{*} \\
(1.089)\end{array}$ & $\begin{array}{l}-4.063^{\star \star} \\
(1.078)\end{array}$ & \\
\hline $\begin{array}{l}\text { Sovereign default probability } \\
\mathbb{P} \text {-default rate }(\%)\end{array}$ & $\begin{array}{c}-0.467 \\
(1.349)\end{array}$ & $\begin{array}{r}-0.330 \\
(1.393)\end{array}$ & $\begin{array}{l}-0.027 \\
(1.531)\end{array}$ & $\begin{array}{c}0.000 \\
(1.382)\end{array}$ & \\
\hline \multicolumn{6}{|l|}{ Panel B. Parameter Estimates } \\
\hline $\begin{array}{l}\text { Firm debt coupon (United States) } \\
C_{d, 0}^{F} \text { (initial level, \%) }\end{array}$ & $\begin{array}{l}2.688^{* \star} \\
(0.049)\end{array}$ & $\begin{array}{l}2.700^{* *} \\
(0.003)\end{array}$ & $\begin{array}{l}2.769^{\star \star} \\
(0.011)\end{array}$ & $\begin{array}{l}2.200^{\star \star} \\
(0.013)\end{array}$ & $\begin{array}{l}2.248^{\star *} \\
(0.009)\end{array}$ \\
\hline $\begin{array}{l}\text { Firm debt coupon (Europe) } \\
C_{f, 0}^{F}(\text { initial level, \%) }\end{array}$ & $\begin{array}{l}3.824^{* \star} \\
(0.006)\end{array}$ & $\begin{array}{l}3.849^{* *} \\
(0.061)\end{array}$ & $\begin{array}{l}3.996^{* *} \\
(0.015)\end{array}$ & $\begin{array}{l}3.032^{\star \star} \\
(0.021)\end{array}$ & \\
\hline $\begin{array}{l}\text { Probability of ending the crisis } \\
\lambda_{L H}(\%)\end{array}$ & $\begin{array}{r}39.87^{\star *} \\
(0.005)\end{array}$ & & $\begin{array}{r}40.01^{* *} \\
(0.087)\end{array}$ & & \\
\hline $\begin{array}{l}\text { Fall in growth during the crisis } \\
\qquad \Delta \theta(\%)\end{array}$ & & $\begin{array}{l}5.009^{* *} \\
(0.005)\end{array}$ & & & \\
\hline \multicolumn{6}{|c|}{ Panel C. Test of Overidentifying Restrictions } \\
\hline $\begin{array}{l}\chi^{2} \\
p \text {-value }\end{array}$ & $\begin{array}{l}0.949 \\
0.622\end{array}$ & $\begin{array}{l}1.054 \\
0.590\end{array}$ & $\begin{array}{c}29.77 \\
0.000\end{array}$ & $\begin{array}{c}9640 \\
0.000\end{array}$ & $\begin{array}{c}51.20 \\
0.000\end{array}$ \\
\hline
\end{tabular}

\section{Main Results}

Column 1 of Table 4 indicates that the model generates levels of equity return volatility and financial leverage in the United States and Europe that match the empirical values. First, Panel A of Table 4 shows that all moments are individually satisfied because the pricing errors are not statistically different from 0 . Second, the $\chi^{2}$ test cannot reject the hypothesis that all five theoretical moments are equal to the empirical moments at the $1 \%$ confidence level (Panel C). Hence, the data do not reject the model, thereby indicating that sovereign default risk matters for equity valuation.

The results show that the market-implied duration of the European sovereign debt crisis is $2.51(=1 / 39.87)$ years (Panel B of Table 4$)$. The estimate is highly significant, both economically and statistically. This duration is in the range of the estimates reported in the literature. Dias and Richmond (2009) find that the median length of sovereign crises is 3 years over the period 1980-2005, whereas Gelos et al. (2011) report a median length of 2 years for crises in the 1990s. 
Arteta and Hale (2008) use micro-level data and find that firms are affected up to 2 years after a sovereign debt restructuration. This structural estimation thus provides an estimate of the asset-implied expected severity of a sovereign default crisis. In comparison, the existing literature has thus far quantified the ex post consequences of sovereign defaults. ${ }^{35}$

Column 2 of Table 4 reproduces the specification of column 1 but estimates the expected contraction in economic growth in Europe upon sovereign default, $\Delta \theta$. The estimate equals $5.01 \%$, which is comparable to the empirical evidence. De Paoli et al. (2009) analyze 39 episodes of sovereign crises for 35 countries over the 1970-2000 period and find a median estimate of output loss that equals $5.25 \%$ per year. Mendoza and Yue (2012) analyze 23 sovereign default crises over the years 1977-2009 and find that the average economic slowdown is 5\%.

The estimation also highlights the importance of corporate debt in the joint explanation of equity return volatility and financial leverage; the estimates of the corporate debt coupons are statistically and economically significant (Panel B of Table 4). In addition, the higher financial leverage in Europe appears to explain the relatively greater volatility in European equity returns. Overall, both sovereign and corporate credit risks appear to be important inputs for equity pricing.

\section{Additional Analysis}

Various alternative model specifications are also tested. As a first analysis, it is useful to investigate the relevance of having heterogeneous firms in the model. To test this feature, I estimate a model with a representative firm in each economy. Column 3 of Table 4 reproduces the benchmark specification (see column 1) under this new assumption. The results suggest that a representative-firm model would have difficulty in explaining, simultaneously, the level of equity volatility and the financial leverage observed in the United States and in Europe. The model would need an excessive level of corporate debt to match the volatility of equity returns. As a result, the $\chi^{2}$ test indicates that the data would reject this version of the model. ${ }^{36}$

How does the model behave if a sovereign default does not affect economic growth? Column 4 of Table 4 addresses this question by reproducing column 1 in the case of $\Delta \theta=0$. The results indicate relatively poor performance of this restricted version of the model; it underestimates the average level of equity volatility by $1.6 \%$ and $1.9 \%$ in the United States and Europe, respectively, and underestimates their financial leverage by $2.6 \%$ and $4.1 \%$ (Panel A). The differences in moments are significant at the $5 \%$ level, leading to a rejection of this specification (Panel C). Hence, a model that ignores the expected adverse consequences of a European debt crisis would have difficulty in explaining the level of equity volatility and the level of financial leverage in Europe and in the United States over the period 1991-2013.

\footnotetext{
${ }^{35}$ As an exception, Andrade and Chhaochharia (2016) also use a structural model to infer the expected costs of default. They use market prices, rather than economic data, as inputs, which makes it more difficult to address the endogeneity between sovereign default risk and equity prices.

${ }^{36}$ The importance of considering an economy with several firms arises from the nonlinear, convex relationship between firm operating costs and equity return volatility (see Figure 2).
} 
A possibility is that European sovereign default risk matters for equity prices but only for European firms. In this case, one would mistakenly reject the explanation of volatility and leverage in the United States. To test this scenario, column 5 of Table 4 reports results from a specification that focuses on U.S. firms and ignores sovereign default risk. The model-implied moments also significantly underestimate their empirical counterparts (Panel A), thereby rejecting this version of the model (Panel C). The difference in financial leverage and equity return volatility is $2.32 \%$ and $1.61 \%$, respectively.

Overall, these results suggest that the risk of a European default crisis appears to be important in explaining the dynamics of equity markets over the 1991-2013 period, not only in Europe but also beyond its borders.

\section{E. Economic Costs of Default in Europe}

The estimation of the model suggests that a sovereign default crisis in Europe would reduce economic growth by approximately 5\% over 2-3 years.

Why would a sovereign crisis induce an economic slowdown in Europe for several years? A likely mechanism through which sovereign default crises can hamper economic growth is the banking system channel. European banks hold a substantial fraction of their assets in the form of government bonds for liquidity purposes. A sovereign default would therefore impact the solvency of banks through losses on their sovereign debt holdings if haircuts were imposed on sovereign creditors. These losses would in turn hamper credit, investment, and output growth. ${ }^{37}$ Gennaioli et al. (2014) suggest that the consequences of a sovereign default in Europe are also expected to be larger than those in emerging markets. The reason is that better institutions increase the sensitivity of credit to the banks' balance sheets, which are themselves more exposed to sovereign default when government debt holdings are higher. This implies that a government's default is expected to be particularly disruptive to private financing in Europe because of the high quality of institutions and the large bank holdings of government debt. In line with this view, the present paper shows that European sovereign default risk has a sizable impact on economic growth and thus on international financial markets.

\section{F. Limits and Extensions}

It is useful to discuss some critical assumptions of the model and extensions for further research. A common shortcoming in sovereign credit risk models is to assume that the economic costs of default and debt relief can be perfectly anticipated. In practice, this is clearly not the case. A related strand of studies (e.g., Pastor and Veronesi (2012), (2013)) shows that the uncertainty of a government's policy has a strong and negative effect on the valuation of equities. Therefore, assuming that investors have imperfect knowledge of the economic consequences of a sovereign default would certainly enhance the effect of sovereign credit risk on equity prices.

Another key assumption is that corporate defaults and taxes have no aggregate effect on a country's consumption level and thus on the pricing

\footnotetext{
${ }^{37}$ A recent strand of research explores this channel in detail (see, e.g., Broner et al. (2010), Bolton and Jeanne (2011), Acharya and Rajan (2013), Acharya et al. (2014), and Gennaioli et al. (2014)).
} 
kernel, following the consumption-based structural models of Bhamra et al. (2010a), (2010b), Chen (2010), and Arnold, Wagner, and Westermann (2013). An alternative would be to introduce deadweight default costs, but modeling optimal default on debt payment would become technically challenging. ${ }^{38}$ In addition, Giesecke, Longstaff, Schaefer, and Strebulaev (2014) find that corporate default crises have no effect on the real economy. Hence, it seems reasonable to assume that neither consumers nor a government's creditworthiness depends on firm defaults.

The representative agents have logarithmic utilities in this paper. The consideration of more general utility functions, such as Epstein-Zin preferences, would be insightful to disentangle risk aversion from intertemporal risk, particularly due to the uncertain length of the default crisis. In that case, the risk-neutral intensity of leaving the default state would be lower than the physical one, thus increasing the effect of sovereign credit risk on equity prices. Unfortunately, beyond the logarithmic case, firm revenue becomes imperfectly correlated, and the problem cannot be solved explicitly as in this paper. The issue that arises is that it is not possible to know whether the government or the firms default first. ${ }^{39}$ However, a potential direction for future research would be to consider a single-economy model and to investigate how the model predictions change with the introduction of richer preferences.

Finally, the framework developed in this paper can lend itself to several extensions for further research. For example, this paper may be useful for investigating how sovereign credit risk affects corporate investment and financing decisions or for improving our understanding of the links between sovereign default risk and exchange rates.

\section{Conclusion}

This article develops a theory to investigate the interactions between sovereign default risk and corporate asset prices at the international level. Specifically, it introduces heterogeneous levered firms, governments, and endogenous default decisions in a two-country asset pricing model. When the theory is applied to the data, this paper provides evidence that the risk of sovereign default in Europe has strongly affected the U.S. equity market.

A structural estimation of the model over the 1991-2013 period shows that the risk of a sovereign debt crisis in Europe translates into the risk of a contraction in economic growth that is statistically and economically significant. Investors account for that risk and reduce their valuation of U.S. equities, thereby increasing the volatility of equity returns. The impact of sovereign default risk on the U.S. equity market is predicted to be strongest when firms are financially vulnerable

\footnotetext{
${ }^{38}$ The equilibrium conditions would all become intertwined, leading to a fixed-point problem that could only be solved using a linear approximation system (e.g., see Bhamra, Fisher, and Kuehn (2011), Gomes and Schmid (2011)).

${ }^{39}$ Modeling firm assets would then require deriving the density at which firm revenue reaches a barrier for the first time, where the firm revenue growth rate depends on a second first-passage time problem involving an imperfectly correlated state variable. The technical issues involved in solving such a model certainly go beyond the objective of this paper.
} 
and sovereign risk is severe. This paper thus offers a new explanation for the low equity prices and high equity return volatility observed internationally during the recent period of economic downturn, with levels of financial leverage that match the data.

The avoidance of the domestic costs of sovereign defaults in terms of economic growth is a prominent reason that governments attempt to repay their debts. However, experience has shown that when governments are unable to service their debt, such costs are by no means avoidable. This paper suggests that a further increase in the default risk of large European sovereign debt issuers (e.g., France or Italy) could have dramatic consequences for international financial markets. Alternatively, steps toward resolving the European debt crisis could be the engine for strong growth in asset prices and a reduction in stock market volatility.

\section{References}

Acharya, V. V.; I. Drechsler; and P. Schnabl. "A Pyrrhic Victory? Bank Bailouts and Sovereign Credit Risk.” Journal of Finance, 69 (2014), 2689-2739.

Acharya, V. V., and R. G. Rajan. "Sovereign Debt, Government Myopia, and the Financial Sector." Review of Financial Studies, 26 (2013), 1526-1560.

Aguiar, M., and M. Amador. "Growth in the Shadow of Expropriation." Quarterly Journal of Economics, 126 (2011), 651-697.

Aguiar, M.; M. Amador; E. Farhi; and G. Gopinath. "Sovereign Debt Booms in Monetary Unions." American Economic Review, 104 (2014), 101-106.

Aguiar, M.; M. Amador; and G. Gopinath. "Investment Cycles and Sovereign Debt Overhang." Review of Economic Studies, 76 (2009), 1-31.

Aguiar, M., and G. Gopinath. "Defaultable Debt, Interest Rates and the Current Account." Journal of International Economics, 69 (2006), 64-83.

Andersen, T. G.; T. Bollerslev; F. X. Diebold; and C. Vega. "Real-Time Price Discovery in Global Stock, Bond and Foreign Exchange Markets." Journal of International Economics, 73 (2007), 251-277.

Andrade, S. C. "A Model of Asset Pricing under Country Risk." Journal of International Money and Finance, 28 (2009), 671-695.

Andrade, S. C., and V. Chhaochharia. "The Costs of Sovereign Default: Evidence from The Stock Market." Working Paper, University of Miami (2016).

Arellano, C. "Default Risk and Income Fluctuations in Emerging Economies." American Economic Review, 98 (2008), 690-712.

Arnold, M.; A. F. Wagner; and R. Westermann. "Growth Options, Macroeconomic Conditions, and the Cross Section of Credit Risk.” Journal of Financial Economics, 107 (2013), 350-385.

Arteta, C., and G. Hale. "Sovereign Debt Crises and Credit to the Private Sector." Journal of International Economics, 74 (2008), 53-69.

Backus, D. K.; S. Foresi; and C. I. Telmer. "Affine Term Structure Models and the Forward Premium Anomaly.” Journal of Finance, 56 (2001), 279-304.

Bae, K.-H.; G. A. Karolyi; and R. M. Stulz. "A New Approach to Measuring Financial Contagion." Review of Financial Studies, 16 (2003), 717-763.

Bakshi, G.; P. Carr; and L. Wu. "Stochastic Risk Premiums, Stochastic Skewness in Currency Options, and Stochastic Discount Factors in International Economies." Journal of Financial Economics, 87 (2008), 132-156.

Bansal, R., and I. Shaliastovich. "A Long-Run Risks Explanation of Predictability Puzzles in Bond and Currency Markets.” Review of Financial Studies, 26 (2012), 1-33.

Bansal, R., and A. Yaron. "Risks for the Long Run: A Potential Resolution of Asset Pricing Puzzles." Journal of Finance, 59 (2004), 1481-1509.

Basak, S., and D. Cuoco. “An Equilibrium Model with Restricted Stock Market Participation.” Review of Financial Studies, 11 (1998), 309-341.

Berrada, T.; J. Hugonnier; and M. Rindisbacher. "Heterogeneous Preferences and Equilibrium Trading Volume.” Journal of Financial Economics, 83 (2007), 719-750.

Bhamra, H.; A. J. Fisher; and L. Kuehn. "Monetary Policy and Corporate Default." Journal of Monetary Economics, 58 (2011), 480-494. 
Bhamra, H.; L. Kuehn; and I. Strebulaev. "The Aggregate Dynamics of Capital Structure and Macroeconomic Risk.” Review of Financial Studies, 23 (2010a), 4187-4241.

Bhamra, H.; L. Kuehn; and I. Strebulaev. "The Levered Equity Risk Premium and Credit Spreads: A Unified Framework.” Review of Financial Studies, 23 (2010b), 645-703.

Black, F. "Studies in Stock Price Volatility Changes." In Proceedings of the American Statistical Association Annual Meetings, Business and Economics Section. Washington, DC: American Statistical Association (1976), 177-181.

Bolton, P., and O. Jeanne. "Sovereign Default Risk and Bank Fragility in Financially Integrated Economies.” IMF Economic Review, 59 (2011), 162-194.

Borri, N., and A. Verdelhan. "Sovereign Risk Premia." Working Paper, Massachusetts Institute of Technology (2012).

Brandt, M. W.; J. H. Cochrane; and P. Santa-Clara. "International Risk Sharing Is Better than You Think, or Exchange Rates Are Too Smooth.” Journal of Monetary Economics, 53 (2006), 671-698.

Broner, F.; A. Martin; and J. Ventura. "Sovereign Risk and Secondary Markets." American Economic Review, 100 (2010), 1523-1555.

Bulow, J., and K. Rogoff. “A Constant Recontracting Model of Sovereign Debt.” Journal of Political Economy, 97 (1989), 155-178.

Chen, H. "Macroeconomic Conditions and the Puzzles of Credit Spreads and Capital Structure." Journal of Finance, 65 (2010), 2171-2212.

Christie, A. A. "The Stochastic Behavior of Common Stock Variances: Value, Leverage and Interest Rate Effects.” Journal of Financial Economics, 10 (1982), 407-432.

Citigroup. "The Debt of Nations." Global Economics View (2011).

Cochrane, J. H.; F. A. Longstaff; and P. Santa-Clara. "Two Trees.” Review of Financial Studies, 21 (2008), 347-385.

Cohen, D., and J. Sachs. "Growth and External Debt under Risk of Debt Repudiation." European Economic Review, 30 (1986), 529-560.

Colacito, R., and M. M. Croce. "Risks for the Long Run and the Real Exchange Rate." Journal of Political Economy, 119 (2011), 153-182.

Cole, H. L., and M. Obstfeld. "Commodity Trade and International Risk Sharing." Journal of Monetary Economics, 28 (1991), 3-24.

Collin-Dufresne, P., and R. S. Goldstein. "Do Credit Spreads Reflect Stationary Leverage Ratios?" Journal of Finance, 56 (2001), 1929-1957.

De Paoli, B.; G. Hoggarth; and V. Saporta. "Output Costs of Sovereign Crises: Some Empirical Estimates." Bank of England Working Paper 362 (2009).

Della Corte, P.; L. Sarno; M. Schmeling; and C. Wagner. "Exchange Rates and Sovereign Risk." Working Paper, Imperial College London (2015).

Dias, D. A., and C. Richmond. "Duration of Capital Market Exclusion: An Empirical Investigation." Working Paper, University of California at Los Angeles (2009).

Dumas, B. "Dynamic Equilibrium and the Real Exchange Rate in a Spatially Separated World." Review of Financial Studies, 5 (1992), 153-180.

Ehrmann, M.; M. Fratzscher; and R. Rigobon. "Stocks, Bonds, Money Markets and Exchange Rates: Measuring International Financial Transmission.” Journal of Applied Econometrics, 26 (2011), 948-974.

Engle, R. F.; E. Ghysels; and B. Sohn. "Stock Market Volatility and Macroeconomic Fundamentals." Review of Economics and Statistics, 95 (2013), 776-797.

Engle, R. F., and J. G. Rangel. "The Spline-GARCH Model for Low-Frequency Volatility and Its Global Macroeconomic Causes.” Review of Financial Studies, 21 (2008), 1187-1222.

Fischer, E. O.; R. Heinkel; and J. Zechner. "Dynamic Capital Structure Choice: Theory and Tests." Journal of Finance, 44 (1989), 19-40.

Forbes, K., and R. Rigobon. "No Contagion, Only Interdependence: Measuring Stock Market Comovements." Journal of Finance, 57 (2002), 2223-2261.

Gelos, R. G.; R. Sahay; and G. Sandleris. "Sovereign Borrowing by Developing Countries: What Determines Market Access?” Journal of International Economics, 83 (2011), 243-254.

Gennaioli, N.; A. Martin; and S. Rossi. "Sovereign Default, Domestic Banks and Financial Institutions." Journal of Finance, 69 (2014), 819-866.

Giesecke, K.; F. A. Longstaff; S. Schaefer; and I. Strebulaev. "Macroeconomic Effects of Corporate Default Crises: A Long-Term Perspective.” Journal of Financial Economics, 111 (2014), 297-310.

Goldstein, R.; N. Ju; and H. Leland. "An EBIT-Based Model of Dynamic Capital Structure." Journal of Business, 74 (2001), 483-512.

Gomes, J. F., and L. Schmid. "Equilibrium Credit Spreads and the Macroeconomy." Working Paper, University of Pennsylvania (2011). 
Gourio, S.; M. Siemer; and A. Verdelhan. "International Risk Cycles.” Journal of International Economics, 89 (2013), 471-484.

Graham, J. R. "A Review of Taxes and Corporate Finance." Foundations and Trends in Finance, 1 (2006), 573-691.

Hackbarth, D.; J. Miao; and E. Morellec. "Capital Structure, Credit Risk, and Macroeconomic Conditions.” Journal of Financial Economics, 82 (2006), 519-550.

Hamilton, J. "A New Approach to the Economic Analysis of Nonstationary Time Series and the Business Cycle.” Econometrica, 57 (1989), 357-384.

Hartmann, P.; S. Straetmans; and C. de Vries. "Asset Market Linkages in Crisis Periods." Review of Economics and Statistics, 86 (2004), 313-326.

Hatchondo, J. C., and L. Martinez. "Long-Duration Bonds and Sovereign Defaults." Journal of International Economics, 79 (2009), 117-125.

Helpman, E., and A. Razin. A Theory of International Trade under Uncertainty. San Diego, CA: Academic Press (1978).

Hilscher, J., and Y. Nosbusch. "Determinants of Sovereign Risk: Macroeconomic Fundamentals and the Pricing of Sovereign Debt." Review of Finance, 4 (2010), 235-262.

Hovakimian, A.; T. Opler; and S. Titman. "The Debt-Equity Choice." Journal of Financial and Quantitative Analysis, 36 (2001), 1-24.

Jeanneret, A. "The Dynamics of Sovereign Credit Risk." Journal of Financial and Quantitative Analysis, 50 (2015), 963-985.

Ju, N.; R. Parrino; A. M. Poteshman; and M. S. Weisbach. "Horses and Rabbits? Trade-Off Theory and Optimal Capital Structure.” Journal of Financial and Quantitative Analysis, 40 (2005), 259-281.

Karolyi, G. A., and R. M. Stulz. "Why Do Markets Move Together? An Investigation of U.S.-Japan Stock Return Comovements.” Journal of Finance, 51 (1996), 951-986.

Korajczyk, R. A., and A. Levy. "Capital Structure Choice: Macroeconomic Conditions and Financial Constraints.” Journal of Financial Economics, 68 (2003), 75-109.

Kyle, A. S., and W. Xiong. "Contagion as a Wealth Effect.” Journal of Finance, 56 (2001), 1410-1440.

Leland, H. E. "Corporate Debt Value Bond Covenants and Optimal Capital Structure." Journal of Finance, 49 (1994), 1213-1252.

Lev, B. "On the Association between Operating Leverage and Risk." Journal of Financial and Quantitative Analysis, 9 (1974), 627-641.

Longstaff, F. A.; J. Pan; L. H. Pedersen; and K. J. Singleton. "How Sovereign Is Sovereign Credit Risk?" American Economic Journal: Macroeconomics, 3 (2011), 75-103.

Lucas, R. E. "Interest Rates and Currency Prices in a Two-Country World." Journal of Monetary Economics, 10 (1982), 335-359.

Lucas, R. E. Models of Business Cycles. New York, NY: Basil Blackwell (1987).

Lucas, R. E., and N. L. Stokey. "Optimal Fiscal and Monetary Policy in an Economy without Capital." Journal of Monetary Economics, 12 (1983), 55-93.

Mello, A., and J. Parsons. "Measuring the Agency Cost of Debt." Journal of Finance, 47 (1992), 1887-1904.

Mendoza, E. G., and V. Z. Yue. "A General Equilibrium Model of Sovereign Default and Business Cycles.” Quarterly Journal of Economics, 127 (2012), 889-946.

Moody’s. "Sovereign Default and Recovery Rates, 1983-2012." Special Comment, Global Credit Policy, New York (2012).

Morellec, E.; B. Nikolov; and N. Schürhoff. "Corporate Governance and Capital Structure Dynamics." Journal of Finance, 67 (2012), 803-848.

Newey, W. K., and K. D. West. "A Simple, Positive Semi-Definite, Heteroskedasticity and Autocorrelation Consistent Covariance Matrix.” Econometrica, 55 (1987), 703-770.

Obstfeld, M., and K. S. Rogoff. Foundations of International Macroeconomics. Cambridge, MA: MIT Press (1996).

Pan, J., and K. Singleton. "Default and Recovery Implicit in the Term Structure of Sovereign CDS Spreads." Journal of Finance, 63 (2008), 2345-2384.

Pastor, L., and P. Veronesi. "Uncertainty about Government Policy and Stock Prices." Journal of Finance, 67 (2012), 1219-1264.

Pastor, L., and P. Veronesi. "Political Uncertainty and Risk Premia." Journal of Financial Economics, 110 (2013), 520-545.

Pavlova, A., and R. Rigobon. "Asset Prices and Exchange Rates." Review of Financial Studies, 20 (2007), 1139-1181.

Rajan, R. G., and L. Zingales. "What Do We Know about Capital Structure? Some Evidence from International Data.” Journal of Finance, 50 (1995), 1421-1460.

Ramsey, F. P. “A Contribution to the Theory of Taxation.” Economic Journal, 37 (1927), 47-61. 
Reinhart, C., and K. Rogoff. This Time Is Different: Eight Centuries of Financial Folly. Princeton, NJ: Princeton University Press (2009).

Remolona, E.; M. Scatigna; and E. Wu. "The Dynamic Pricing of Sovereign Risk in Emerging Markets: Fundamentals and Risk Aversion.” Journal of Fixed Income, 17 (2008), 57-71.

Schwert, W. G. "Why Does Stock Market Volatility Change over Time?" Journal of Finance, 44 (1989), 1115-1153.

Strebulaev, I. A. "Do Tests of Capital Structure Theory Mean What They Say?" Journal of Finance, 62 (2007), 1747-1787.

Van Ark, B.; M. O'Mahony; and M. P. Timmer. "The Productivity Gap between Europe and the United States: Trends and Causes.” Journal of Economic Perspectives, 22 (2008), 25-44.

Verdelhan, A. "A Habit-Based Explanation of the Exchange Rate Risk Premium." Journal of Finance, 65 (2010), 123-145.

Yue, V. Z. "Sovereign Default and Debt Renegotiation." Journal of International Economics, 80 (2010), 176-187.

Zapatero, F. "Equilibrium Asset Prices and Exchange Rates." Journal of Economic Dynamics and Control, 19 (1995), 787-811. 